2008

\title{
The Track Record on Takings Legislation: Lessons from Democracy's Laboratories
}

John D. Echeverria

Georgetown University Law Center

Thekla Hansen-Young

Georgetown University Law Center

This paper can be downloaded free of charge from:

http://scholarship.law.georgetown.edu/gelpi_papers/1 


\section{THE TRACK RECORD ON TAKINGS LEGISLATION}

\section{Lessons from Democracy's Laboratories}

John D. Echeverria

Thekla Hansen-Young

Georgetown Environmental Law \& Policy Institute Georgetown University Law Center 


\section{About the Authors:}

John D. Echeverria is the Executive Director of the Georgetown Environmental Law \& Policy Institute at Georgetown University Law Center. $\mathrm{Mr}$. Echeverria is the former General Counsel of the National Audubon Society, the former General Counsel and Conservation Director of American Rivers, Inc., and a graduate of the Yale Law School and the Yale School of Forestry and Environmental Studies. In 2007, he received the Jefferson Fordham Advocacy Award from the American Bar Association to recognize outstanding excellence within the area of state and local government law over a lifetime of achievement.

The Georgetown Environmental Law \& Policy Institute conducts research and education on legal and policy issues related to protection of the environment and conservation of natural resources. The Institute publishes papers and reports by leading academics and practitioners applying rigorous analysis to contemporary environmental and natural resource issues. The views expressed in Institute publications are those of the authors and do not necessarily reflect the views of the Institute's board of advisors or Georgetown University.
Thekla Hansen-Young is a Fellow at the Georgetown Environmental Law \& Policy Institute. Ms. HansenYoung is a 2005 honors graduate of the University of Chicago School of Law, where she served as a staff member of the University of Chicago Law Review, and is a summa cum laude graduate of New York University. Ms. Hansen-Young served as law clerk to Judge Rosemary Barkett of the U.S. Court of Appeals for the Eleventh Circuit in 2006-2007 and as law clerk to Judge Helen G. Berrigan of the U.S. District Court for the Eastern District of Louisiana in 2005-2006. She has published several law review articles on natural resources and Native American topics.

Copyright @2008 Georgetown University. All rights reserved. No part of this publication may be reproduced in any form without prior consent of the publisher. 


\section{THE TRACK RECORD ON TAKINGS LEGISLATION}

\section{Lessons from Democracy's Laboratories}

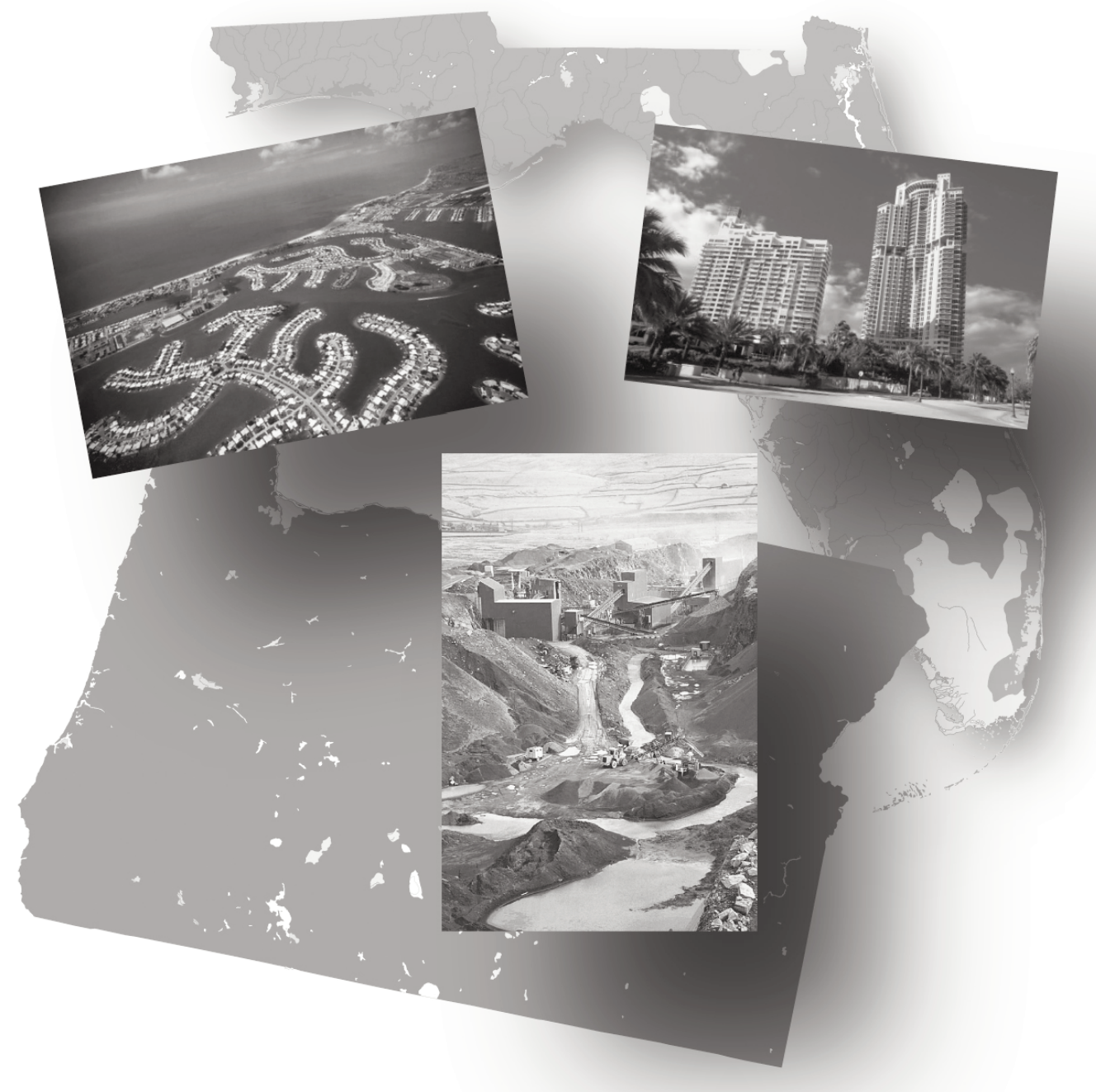

John D. Echeverria

Thekla Hansen-Young

Georgetown Environmental Law \& Policy Institute Georgetown University Law Center 


\section{Introduction and Executive Summary}

"The grand plan was to make government pay compensation as for a taking of property every time its regulations impinged too severely on a property right-limiting the possible uses for a parcel of land or restricting or tying up a business in regulatory red tape. If the government labored under so severe an obligation, there would be, to say the least, much less regulation."

Charles Fried, ORDER AND LAw, ARGUING THE REAGAN

REVOLUTION-A FiRSTHAND ACCOUNT 183 (1991).

"It is one of the happy accidents of our federal system that a single courageous state may, if its citizens choose, serve as a laboratory, and try novel social and economic experiments without risk to the rest of the country."

Justice Louis Brandeis, dissenting in New State Ice Co. v. Liebmann, 285 U.S. 262, 311 (1932).

This report examines the experiences of two states, Florida and Oregon, with so-called takings "compensation" measures. The goal of the report is to identify the lessons from these states that might be useful to citizens and policy makers in other jurisdictions considering similar measures.

For the last twenty years there has been a nationwide debate about whether government should be required to pay property owners to comply with land use and environmental rules, above and beyond the protection for property owners provided by the U.S. and state constitutions. Property rights advocates have argued that requiring the public to pay to enforce regulatory requirements would improve the fairness of regulatory programs and force government officials to make more judicious and discriminating decisions about the regulations they adopt and enforce. ${ }^{1}$ Opponents have argued that such a compensation mandate would undermine the public's ability to implement community protections and impose unfair financial burdens on taxpayers. ${ }^{2}$

At least so far, the U.S. Congress has rejected takings compensation proposals. ${ }^{3}$ The majority of states have rejected these proposals as well, although many states have adopted more limited forms of private property rights legislation. ${ }^{4}$ However, half a dozen states have adopted

${ }^{1}$ E.g., E. Donald Elliott, How Takings Legislation Could Improve Environmental Regulation, 38 WM. \& MARY L. REV. 1177, 1178 (1997).

2 E.g., Glenn Sugameli, Takings Bills Threaten Private Property, People, And The Environment, 8 FORDHAM ENVTL. L. J. 521, 567-80 (1997).

3 See Georgetown Environmental Law \& Policy Institute, Regulatory Takings Legislation, at http://www.law.georgetown.edu/gelpi/current_research/regulatory takings/takings_legis.cfm (collecting failed property rights proposals in Congress).

${ }^{4}$ See Harvey M. Jacobs, STATE PROPERTY Rights LAWs; THE IMPACTS OF THOSE LAWS ON MY LAND (Lincoln Institute 1999); John D. Echeverria, REFLECTIONS ON MEASURE 7, 1000 FRIENDS OF OREGON MCCALl SPEAKERS PROGRAM (May 31, 2001), at http://www.law.georgetown.edu/gelpi/current_research/documents/RT_Pubs_Speeches_Reflections OrMeas7.pdf. 
legislation that explicitly requires the government to pay property owners subject to regulatory restrictions when the restrictions do not amount to "takings" under the federal or state constitutions.

This report focuses on Florida and Oregon because these states have adopted the broadest and, at least from the perspective of property rights advocates, the most successful measures. In 1995, Florida adopted legislation that includes two separate but related measures, the Bert J. Harris Private Property Rights Act and the Florida Land Use and Environmental Dispute Resolution Act. In 2004, Oregon voters adopted Measure 37, and three years later adopted Measure 49, which partly reversed Measure 37. The report also discusses, in more summary fashion, the consequences of takings compensation legislation in the several other states that have embraced this legislative agenda, including Arizona, Louisiana, Mississippi, and Texas.

These state measures provide an opportunity to examine the consequences of adopting the property rights agenda. The states are serving as laboratories, to use Justice Brandeis's apt phrase, producing potentially valuable information for other jurisdictions grappling with the takings issue. In particular, Californians will have an opportunity to vote on two competing property rights proposals in June 2008, one of which, Proposition 98, arguably would require the government to pay to enforce land use and environmental laws. ${ }^{5}$ Other states or the U.S. Congress may also debate the takings issue in the future.

While the experiences with the takings agenda in Florida and Oregon (as well as the other states) vary in important respects, our analysis leads to five overarching conclusions:

The Takings Agenda Undermines Community Protections. The virtually invariable effect of takings legislation, to the extent it has been effective, has been to force state and local governments to not adopt laws and regulations they otherwise would have adopted and to not enforce restrictions already on the books. Despite their label as "compensation" measures, this legislation has only very rarely resulted in actual payments to property owners. Nor has takings legislation resulted in more discriminating or judicious use of regulatory authority. Instead, these measures have essentially blocked the enactment of any significant new community protections and severely undermined the protections that pre-dated the measures.

Special Interests Benefit the Most from the Takings Agenda. While the property rights agenda is generally advertised as being for and on behalf of the "little guy," the primary beneficiaries of the property rights agenda have been relatively well to do special interests. In Oregon, the primary beneficiaries of Measure 37 have been timber companies seeking the

5 California Center for Environmental Law \& Policy, CALIFORNIA's PROPOSITION 98 \& 99: A COMPARATIVE ANALYSIS (Berkeley May 2008), available at http://www.law.berkeley.edu/centers/envirolaw/Prop_98-99_Analysis-1.pdf; Shute, Mihaly \& Weinberger Letter to Susan Smartt, California League of Conservation Voters Education Fund (Dec. 6, 2007), available at www.ecovote. org/no98yes99/smw-letter-re-jarvis. pdf. 
opportunity to subdivide and sell off their resource lands and/or wishing to avoid new restrictions on timber harvesting practices. In Florida, the primary beneficiaries of property rights legislation have been real estate developers and corporate land owners. Developers and owners of vacant, developable land have benefited at the expense of the rest of society, including homeowners whose community protections have been undermined.

The Takings Agenda Generates Land Use Conflicts. The property rights agenda has fostered additional land use controversy, generating litigation and other legal claims and creating conflicts between neighboring land owners. The conflicts generated by the Florida property rights legislation have been particularly intense in urban areas and in the urbanizing fringe, while the Oregon property rights legislation has primarily produced land use conflicts in rural agricultural and forest lands.

The Takings Agenda Confers Special Windfalls. Takings measures have conferred windfalls - either in the form of actual payments or, far more frequently, legal exemptions from regulations - by permitting certain land owners to evade the responsibilities that apply to the rest of the community. Economics research demonstrates that comprehensive land use regulatory programs have little if any net adverse effect on property values. Thus, takings "compensation" awards, far from providing a remedy for significant regulatory burdens, generally provide claimants windfalls based on the inflated value of special exemptions from the rules and regulations that apply to everybody else.

The Takings Agenda Undermines Local Democracy. Finally, the property rights agenda has undermined democratic government, especially at the local level. The property rights measures have very seriously impaired communities' capacity to enact new land use laws and limited the opportunities for members of the public to advocate for and defend their communities.

This report is organized as follows. The next section describes in detail Florida's 1995 property rights legislation, discusses how the legislation altered the balance of power in the state between developers and other large land owners and the general public, and addresses Florida's Hometown Democracy movement, the grassroots response to the success of the property rights movement in Florida. The following section describes in detail Oregon's Measure 37, the torrent of legal claims against the state and local governments produced by this measure, and the consequences for Oregon's comprehensive land use program. It concludes with a discussion of recently adopted Oregon Measure 49 and its significance. The final section discusses in some detail the five major lessons, set forth above, that we have drawn from this study. 


\section{Florida Property Rights Legislation}

Introduction

On May 18, 1995, the State of Florida adopted what is arguably the most far-reaching property rights legislation in the country. ${ }^{6}$ The legislation has two separate, but closely related parts. The Bert J. Harris, Jr. Private Property Rights Protection Act created a judicially enforceable right to financial compensation based on "burdensome" regulatory restrictions on the use of real property. ${ }^{7}$ The Florida Land Use and Environmental Dispute Resolution Act created a mediation process designed to permit land owners to obtain relief from allegedly "unfair" or "unreasonable" restrictions. ${ }^{8}$

Florida adopted takings legislation against the backdrop of the state's comprehensive land use regulatory program. Adopted in the 1970s and 80s in response to public concerns about the social and environmental impacts of rapid development, ${ }^{9}$ Florida's primary land use laws include the Florida State Comprehensive Planning Act of 1972, ${ }^{10}$ the Florida Environmental Land and Water Management Act of 1973, ${ }^{11}$ and the Local Government Comprehensive Planning and Land Development and Regulation Act of $1985 .{ }^{12}$ Together, these statutes require the state to adopt and maintain a State Comprehensive Plan establishing goals and policies to guide Florida's growth, require local governments to adopt comprehensive plans and implementing regulations, and provide for state and regional oversight of growth management policies across the state. ${ }^{13}$ Subsequent enactments strengthened Florida's land use system by directing development away from barrier islands and other high-hazard coastal areas, creating incentives to promote more compact urban development patterns, and requiring concurrency between new development authorized by local governments and local infrastructure capacity. ${ }^{14}$ While the Florida property rights legislation did not formally amend this legislation, it has drastically altered its effectiveness.

One hallmark of the Florida land use program has been extensive opportunities for public involvement. The Local Government Comprehensive Planning and Land Development Regulation Act declares that "It is the intent of the Legislature that the public participate in the comprehensive planning process to the fullest extent possible." ${ }^{15}$ Members of the public have broad rights to

61995 Fla. LawS CH. 95-181 (C.S.H.B. 863) (codified at FLA. ST. ANN. § 70.001 and $§ 70.51$ ). Oregon Measure 37 was even more far reaching before it was amended by Measure 49.

7 FLA. ST. ANN. $\$ 70.001$.

8 FLA. ST. ANN. § 70.51.

9 David J. Russ, How the "Property Rights" Movement Threatens Property Values in Florida, 9 J. LAND USE \& ENVTL. L. 395, 410-12 (1994).

10 FLA. ST. ANN. $\$ \S 186.001-186.031,186.801-186.901$.

11 FLA. ST. ANN. \$ 380.012, et seq.

12 Fla. St. ANN. § 163.3161, et seq.

13 FLA. ST. ANN. \$\$ 163.3167(2), 163.3194, 163.3202.

14 FLA. ST. ANN. \$§ 163.3178, 163.3180, 163.2511-163.2526.

15 Fla. St. ANN. § 163.3181(1). 
initiate and intervene in local proceedings involving comprehensive plans, ${ }^{16}$ as well as more limited standing to challenge approvals of particular development projects in court. ${ }^{17}$ Again, the property rights legislation significantly changed the role of the public in the land use process.

The Florida takings legislation was adopted at the height of the private property rights movement, both nationally and in Florida. ${ }^{18}$ The debate over takings in Florida consumed several years and featured a gubernatorial study commission on the topic, a proposed state constitutional amendment, and numerous competing legislative proposals. ${ }^{19}$ Major corporate property owners were the driving force behind the push for legislation, although they succeeded in enlisting numerous ideological allies and building a populist base of support. ${ }^{20}$ By 1995 , following a shift in control of the legislature to the Republican Party, a political consensus emerged that some type of property rights legislation was inevitable. The final legislation emerged from a bi-partisan negotiation process organized by Governor Lawton Chiles, a Democrat. ${ }^{21}$

The basic objective of the Bert Harris Act is clear: to expand upon the protections provided to property owners by the Takings Clauses of the United States and Florida Constitutions. The Bert Harris Act begins by stating

The Legislature recognizes that some laws, regulations, and ordinances of the state and political entities in the state, as applied, may inordinately burden, restrict, or limit private

16 FLA. ST. ANN. $\S \S 163.3184(9)-(10)$ (authorizing formal initiation of or intervention in administrative hearings on comprehensive plan amendments); FLA. ST. ANN. § 163.3181 (same). See also FLA. ST. ANN. § 163.3215(4) (stating that local administrative proceedings "must provide an opportunity for participation in the process by an aggrieved or adversely affected party, allowing a reasonable time for the party to prepare and present a case for the quasi-judicial hearing").

17 FLA. ST. ANN. $\$ 163.3215$ (3) ("Any aggrieved or adversely affected party may maintain a de novo action for declaratory, injunctive, or other relief against any local government to challenge any decision of such local government granting or denying an application for, or to prevent such local government from taking any action on, a development order, as defined in s. 163.3164, which materially alters the use or density or intensity of use on a particular piece of property which is not consistent with the comprehensive plan adopted under this part.”); FLA. ST. ANN. § 163.3215(4) (providing that parties may challenge decisions by "an appeal filed by a petition for writ of certiorari filed in circuit court"). See also Board of County Com'rs of Brevard County v. Snyder, 627 So.2d 469, 474-76 (Fla. 1993) (establishing that some land use decisions are "quasi-judicial" and thus "subject to review by certiorari" and "will be upheld only if they are supported by substantial competent evidence").

18 See Robert Meltz, Federal Regulation of the Environment and the Taking Issue, 37 FED. B. NeWs \& J. 95 (Feb. 1990).

19 Sylvia R. Lazos Vargas, Florida's Property Rights Act: A Political Quick Fix Results in Mixed Bag of Tricks, 23 FLA. ST. U. L. REV. 315, 327-333 (1995).

${ }^{20}$ Id. at 329 n. 65 (observing that St. Joe Paper Company, U.S. Sugar Corporation, Lykes Brothers, Collier Enterprises, and A. Duda \& Sons "were among the most powerful corporate sponsors of the property rights movement in 1994").

${ }_{21} I d$. at 318 ("The Act, although passed on the next to the last day of the session, represented a compromise painstakingly crafted over weeks of intense negotiations among an ad hoc group of Senators and Representatives who were longtime property rights activists, key executives representing land use agencies, lobbyists for developers and small and large agricultural interests, environmentalists, and state and local governments."). 
property rights without amounting to a taking under the State Constitution or the United States Constitution. The Legislature determines that there is an important state interest in protecting the interests of private property owners from such inordinate burdens. ${ }^{22}$

It is less clear what the Act's proponents thought the consequences of this new policy would be. Governor Chiles predicted that Florida's regulatory programs would remain largely intact: "[W]e can be proud of this legislation. It safeguards our environmental and growthmanagement protections while also offering private property owners a means to seek compensation for devalued land." 23 Other close observers predicted that the law would not result in "an explosion of litigation or a rash of damage awards" but rather would "produce a sense of caution" among government officials. ${ }^{24}$

The goal of the Dispute Resolution Act was to reduce the stringency and increase the flexibility of regulatory controls by providing land owners an additional opportunity, once the normal land use regulatory review process was complete, to seek relief from "unreasonable" or "unfair" regulations. In contrast to the Bert Harris Act, the primary purpose of which was to create new substantive protection for private property rights, the Dispute Resolution Act granted property owners new procedural rights to object to and obtain relief from regulations.

\section{The Florida Property Rights Laws}

This section provides a sketch and analysis of the primary provisions of the Bert Harris Act and the Dispute Resolution Act as a prelude to a more extensive discussion of the consequences of the adoption of these measures, especially the Bert Harris Act.

The Bert Harris Act. The Bert Harris Act creates a right of action to recover financial compensation or other relief when a regulatory decision or other government action "inordinately burden[s] an existing use of real property." ${ }^{25}$ Importantly, and confusingly, the term "existing use" does not have its ordinary meaning, because it encompasses not only actual existing uses but also certain future uses. Specifically, the Act defines a proposed future use to be an existing use for the purposes of the Act if five conditions are met: the use (1) is "reasonably foreseeable," (2) is "non-speculative," (3) is "suitable for the subject real property," (4) is "compatible with adjacent

${ }^{22}$ Fla. ST. ANN. § 70.001(1).

23 Roy Hunt, Property Rights and Wrongs: Historic Preservation and Florida's 1995 Private Property Rights Protection Act, 48 FLA. L. REV. 709, 715 (1996). See also Ron Weaver, Bert Harris Update (1997) ("Wetlands, woodpeckers, scrubjays, and the like should be protected generally, but owners need no longer bear disproportionate shares of the burden of that protection.").

24 David L. Powell, Robert M. Rhodes, \& Dan R. Stengle, A Measured Step to Protect Private Property Rights, 23 FLA. ST. U. L. REV. 255, 296 (1995).

25 Fla. ST. ANN. § 70.001(2). 
land uses," and (5) creates "an existing fair market value in the property greater than the fair market value of the actual, present use or activity on the real property. "26

While this definition appears to be limiting, the Act actually applies quite broadly to regulations affecting future land uses. Many of the conditions listed above are ambiguous and do not establish clear restrictions on the kinds of potential future uses covered by the Act. The requirement that a proposed use be "compatible with adjacent land uses" is potentially the most significant, because it arguably excludes major development projects in undeveloped rural areas. But assuming this is correct, an "existing use" still arguably includes virtually any potentially profitable development opportunity in Florida's urban centers or in the urbanizing fringe.

The other key term in the Act - "inordinate burden" - is defined as a government action that has directly restricted or limited the use of real property such that [1] the property owner is permanently unable to attain the reasonable, investment-backed expectations for the existing [i.e., or proposed] use of the real property or [2] the property owner is left with existing [i.e., or proposed] uses that are unreasonable such that the property owner bears permanently a disproportionate share of a burden imposed for the good of the public, which in fairness should be borne by the public at large. ${ }^{27}$

This provision creates two alternative paths for demonstrating the existence of an inordinate burden. First, the claimant can attempt to show that her development plans are based upon a "reasonable, investment-backed expectation" for use of the property and that the regulation bars her from "attaining" this expectation. Second, an owner can attempt to show that the restriction is "unreasonable" in the sense that the owner is left with such limited uses of the property that she has been forced to bear a burden that "in fairness should be borne by the public at large."

The inordinate burden standard is clearly far more expansive than the constitutional takings standard, ${ }^{28}$ and indeed goes beyond any reading of the federal Takings Clause ever offered by any justice of the U.S. Supreme Court. Generally speaking, a regulatory taking occurs only in

26 Fla. ST. ANN. $\$ 70.001(3)(\mathrm{b})$.

27 FLA. ST. ANN. § 70.001(3)(e).

28 Commentators have offered different views on how far the inordinate burden standard diverges from constitutional doctrine. Some contend that it represents only a "cautious and modest" expansion of constitutional takings doctrine, which is "not intended to drastically affect Florida's growth management or environmental laws." Richard Grosso \& Robert Hartsell, Old McDonald Still Has a Farm: Agricultural Property Rights After the Veto of S.B. 1712, FLA. BAR. J. (Mar. 2005). Others contend that the inordinate takings standard has more bite. As one commentary observed, "You can make the argument that Florida's legislature wouldn't have gone to so much trouble if all they meant to do was to make it a little easier for land owners to gain compensation." Charles C. Carter \& John Taylor, Current Status of Property Rights Compensation States, 33 REAL EstateL. J. 405, 411 (2005). See also Julian Conrad Juergensmeyer, Florida's Private Property Rights Protection Act: Does it Inordinately Burden the Public Interest?, 48 FLA. L. REV. 695, $697-$ 706 (1996) (offering a highly critical appraisal of the Bert Harris Act). 


\section{Arizona}

In November 2006, Arizona voters approved, by a margin of $65 \%$ to $35 \%$, Proposition 207 , or the Private Property Rights Protection Act. ${ }^{a}$ The Act includes a pay or waive provision closely modeled after Oregon Measure 37, , and another provision, responding to the Supreme Court decision in Kelo v. City of New London, ${ }^{\mathrm{c}}$ restricting the use of eminent domain for economic development. $^{\mathrm{d}}$ The yes campaign spent $\$ 1.8$ million, most of it contributed by Americans for Limited Government, "a group led by New York real estate mogul Howard Rich," in comparison to the opponents' relatively paltry budget of $\$ 420,000{ }^{\mathrm{f}}$

While the drafters of the Arizona proposition used Measure 37 as their starting point there are several important differences. Most significantly, whereas Measure 37 had broad retroactive effect, the Arizona proposition only applies to laws adopted following its enactment. ${ }^{\mathrm{g}}$ The drafters of the Arizona proposition also tinkered with the Measure 37 exemptions, for example, by exempting regulations restricting the use of property for "housing of sex offenders, selling illegal drugs, liquor control, or pornography [or] obscenity," and (somewhat ambiguously) laws that that "[d] o not directly regulate an owner's land." $\mathrm{h}$ In addition, the Arizona proposition avoided some of the drafting problems with Measure 37 by making clear that waivers are transferable and that the government entity that enacts a law (as opposed to enforces it) would be liable to pay compensation. ${ }^{\mathrm{j}}$

Arizona's takings proposition already has had dramatic effects, in particular on the State's historic preservation efforts. The City of Flagstaff is the target of the first lawsuit under the Private Property Rights Protection Act, brought by several land owners objecting to the creation of an overlay district in the City's most historic neighborhood. ${ }^{\mathrm{k}}$ The plaintiffs demanded $\$ 368,000$ in compensation. ${ }^{1}$ One historic preservation advocate objected to the owners' proposals to tear down small historic buildings and build larger modern structures, stating: "We're trying to stop this from happening anymore. It's not what we wanted to live around when we bought here."

Tuscon may not be far behind. A developer of "minidorms" near the University of Arizona has threatened to sue the city for $\$ 12.6$ million based on a "regulation passed by the City Council ... [that] requires a historic study be done on any 45-year-old or older building in Tucson's historic core . . . before it can be torn down" and allows the City up to six months following the study to determine if "it wants to buy the property or find a private buyer." lawyer representing the developer was quoted in the local press as stating that he "hope[d] to trigger a flood of Proposition 207 claims from other property owners by printing easy to use fill-in-

${ }^{a}$ AZ. REv. ST. $\S$ 12-1131-38; Daniel Kraker, Growth Unfettered, HiGH COUNTRY NEwS, November 26, 2007; Front, ARIZONA REPUBLIC, Sept. 29, 2007.

b AZ. REV. ST. § 12-1134.

c 545 U.S. 469 (2005).

d AZ. REV. ST. $\S \S 12-1131,1133,1136$.

e Amanda J. Crawford, After Smoke Cleared, A look at Finances, ARIZONA REPUBLIC, Dec. 24, 2006.

f $I d$.

g AZ. REV. ST. § 12-1134(B)(7).

h AZ. REV. ST. § 12-1134(B).

i AZ. REV. ST. § 12-1134(F).

j AZ. REV. ST. § 12-1134(A).

k Kraker, Growth Unfettered.

${ }^{1}$ Id.; J. Ferguson, Property rights test case filed, ARIZONA DaILy Sun, June 29, 2007.

m Kraker, Growth Unfettered.

${ }^{\mathrm{n}}$ Rob O’Dell, Minidorm developer threatens $\$ 12 M$ suit, ARIZONA DAILY STAR, Sept. 15, 2007. 
the-blank claim forms. ${ }^{\circ}$ Another developer said the City's total liability could reach $\$ 500$ million. $^{\mathrm{p}}$ Similarly, in Pinal County, a developer has threatened a half-million dollar lawsuit based on the reversion of the zoning on a property to farm use after the owner failed to proceed in timely fashion with an authorized development project ${ }^{\mathrm{q}}$

In addition, the proposition has already had a chilling effect in several communities. The threat of a \$40 million dollar lawsuit reportedly led the City of Phoenix to repeal a historic district it established in 2007. ${ }^{\mathrm{r}}$ Mayor Phil Golden was quoted as saying that the repeal occurred "on the advice of attorneys," and that he had "a fiduciary duty to the citizens not to risk $\$ 40$ million." One resident concluded: "The ability to establish new historic districts . . . is nearly impossible because of Proposition 207." $t$ In Tempe, citizens withdrew an application for the establishment of a historic district after opponents threatened to sue under Proposition 207 and it appeared likely that the City would reject the application based on this threat. " In Tucson, the proposition may thwart efforts to promote in-fill development through adoption of a "neighborhood preservation zoning overlay" plan. " Colette Altaffer, president of the Catalina Vista Neighborhood Association and a founder of the Neighborhood Infill Coalition, said that "Proposition 207 has rendered us toothless, unfortunately. It locked us into where we were with an existing code. You can't tighten it without facing a challenge, and you're really reluctant to loosen it."w

According to another observer, while "on the surface" Proposition 207 "sounds fair enough, ... it creates a nightmare because it mainly vests real estate entrepreneurs with the ability to circumvent the will of the majority of residents in any given neighborhood."x

${ }^{\circ} I d$.

p $I d$.

q Lynh Bui, Property Rights Suit Threatened, ARIZONA RePuBLIC, Feb. 10, 2008.

${ }^{\mathrm{r}}$ Minidorm issue may trigger necessary lawsuits, ARIZONA DAILY STAR, Aug. 8, 2007; Laurie Roberts, Developer Takes on City Hall and Wins, Thanks to Prop. 207, ARIZONA REPUBLIC, Apr. 14, 2007.

s $I d$.

t Diana Balazs, Prop. 207 Hampers Municipalities, ARIZONA RePuBlic, Sept. 29, 2007.

u Garin Groff, Tempe neighborhood's historical status on hold: City's oldest area looks at new way to achieve designation, TRIBUNE, Sept. 7, 2007; Handling history: Memories shouldn't erode private-property rights, TRIBUNE, Aug. 22, 2007.

Tom Beal, Pilot plans disappoint Midtown neighbors, ARIZONA DAILY STAR, Jan. 27, 2008.

w $I d$.

x Minidorm issue may trigger necessary lawsuits, ARIZONA DAILY STAR, Aug. 8, 2007. 
"extreme circumstances" 29 when a regulation is so burdensome that it is the "functional equivalent" of a physical occupation or an outright condemnation. ${ }^{30}$ Outside of the narrow per se category of "total" takings, ${ }^{31}$ regulatory takings claims are generally evaluated using an ad hoc analysis focusing on the economic impact of the government action, the degree to which it interferes with the owner's reasonable investment-backed expectations, and the character of the government action. $^{32}$ This analysis may encompass various considerations but typically addresses, in addition to economic impact, whether the claimant was aware of the regulation when he purchased the property or could have reasonably anticipated its adoption, the degree to which the regulation singles out an owner for special treatment or is comprehensive in nature, and whether the regulation is designed to prevent activities that the legislature has determined are harmful to the public welfare. $^{33}$

By contrast, under the inordinate burden standard, and focusing on the more expansive part of the definition, an owner is entitled to compensation if a regulation permanently bars her from "attaining" her "reasonable, investment-backed expectations." Under this test, the economic burden imposed by a regulation (if any), the relative comprehensiveness of the regulation, or the potential harmfulness of the proposed development, all become irrelevant. Any developer who has purchased property in an urban or urbanizing area with a plan to develop it can make a strong claim that the imposition of virtually any new regulatory constraint represents a compensable action. ${ }^{34}$ This takings standard plainly hamstrings the ability of state and local governments to respond to challenges posed by new scientific information, changed circumstances, or evolving social values.

While the "investment-backed expectations" language is borrowed from constitutional takings doctrine, the Act says that the courts are free to disregard how this language has been interpreted in that context. ${ }^{35}$ Thus, this term could take on a new and different meaning in Florida's

\footnotetext{
${ }^{29}$ United States v. Riverside Bayview Homes Inc., 474 U. S. 121, 126 (1985).

30 Lingle v. Chevron U.S.A. Inc., 544 U.S. 528, 539 (2005).

31 Lucas v. South Carolina Coastal Council, 505 U.S. 1003 (1992).

32 Lingle, 544 U.S. at 538-539.

33 John D. Echeverria, Making Sense of Penn Central, 23 UCLA J. ENVTL. L. \& POL'Y 171, 17899 (2005).

34 The second path for establishing an inordinate burden effectively converts the so-called Armstrong principle-the U.S. Supreme Court's of ten-quoted statement that the Takings Clause is "designed to bar Government from forcing some people alone to bear public burdens which, in all fairness and justice, should be borne by the public as a whole" - into a freestanding takings test. Armstrong v. United States, 364 U.S. 40, 49 (1960). While the Armstrong principle is a central element of modern takings doctrine, the Supreme Court has never suggested that it can serve as a determinative test for deciding when compensation is due. It is hard to say how, if at all, this takings test would diverge from the traditional constitutional takings test.

35 FLA. ST. ANN. § 70.001(9) (stating that the Act's terms "may not necessarily be construed under the case law regarding takings if the government action does not rise to the level of a taking").
} 
statutory takings regime, lending further support to the conclusion that the inordinate burden standard diverges significantly from the constitutional takings test.

The Bert Harris Act, unlike Oregon's Measure 37, is purely prospective, that is, it only applies to restrictions adopted after May 11, 1995. ${ }^{36}$ This represents a significant limitation on the scope of the law. The Act also includes several other exemptions, including for "temporary" limitations on real property use (e.g., development moratoria), impacts to private property resulting from government efforts to abate or otherwise address a "public nuisance" or a "noxious use of private property," as well as government actions "taken to grant relief" to a developer or other property owner under the Act (i.e., neighbors cannot assert a claim under the Act on the ground that they have been harmed by relief granted to a claimant objecting to regulations as too burdensome). ${ }^{37}$

To initiate a proceeding, a land owner must submit a "claim" along with a "bona fide, valid appraisal that supports the claim and demonstrates the loss in fair market value to the real property." 38 The government must provide written notice of the claim to members of the public who were "parties" to the underlying administrative proceeding, to owners of contiguous properties, and to the Florida Department of Legal Affairs. ${ }^{39}$ Within 180 days of receipt of the claim (90 days in the case of agricultural lands), the government must respond with a "written settlement offer." 40 The "offer" can run the gamut from complete rejection of the claim, to modification of the regulatory action, to purchase of the property, to new conditions or mitigation measures.

If a settlement is reached and the government agrees to modify its decision, "the relief granted shall protect the public interest served by the regulations at issue and be the appropriate relief necessary to prevent the government regulatory effort from inordinately burdening the property." 41 If the settlement "would have the effect of contravening the application of a statute as it would otherwise apply to the subject real property," the parties must obtain Circuit Court approval of the settlement agreement. ${ }^{42}$

36 FLA. ST. ANN. $§ 70.001(12)$. See also id. (stating that an amendment to a pre-existing restriction "gives rise to a cause of action ... only to the extent that the application of the amendatory language imposes an inordinate burden apart from the law, rule, regulation, or ordinance being amended" and that the Act does not apply to any rule, regulation, or ordinance "formally noticed for adoption" prior to the Act's effective date).

37 FLA. ST. ANN. § 70.001(3)(e). In addition, the Act excludes claims based on government transportation facilities, state, regional, or local actions under delegated federal authority, and repetitive claims for loss in value to the same property. FLA. ST. ANN. $\$ \$ 70.001(10),(3)(c),(9)$.

38 FLA. ST. ANN. $\$ 70.001(4)(\mathrm{a})$.

39 FLA. ST. ANN. § 70.001(4)(b).

40 FLA. ST. ANN. $\$ 70.001(4)(\mathrm{c})$.

41 Fla. ST. ANN. $\$ 70.001(11)(d)$.

42 Fla. ST. ANN. § 70.001(11)(d). 
If the parties fail to reach agreement, the government must issue a "ripeness decision" specifying what property uses it will allow. ${ }^{43}$ Upon issuance of this decision (or if the government fails to issue a decision), the land owner can sue in Circuit Court for compensation or other relief. ${ }^{44}$ If the court determines that the government action imposed an inordinate burden it must impanel a jury to fix appropriate compensation. ${ }^{45}$ The Act provides that the jury's compensation award shall be determined by calculating the difference in the fair market value of the real property, as it existed at the time of the governmental action at issue, as though the owner had the ability to attain the reasonable investment-backed expectation or was not left with uses that are unreasonable, whichever the case may be, and the fair market value of the real property, as it existed at the time of the governmental action at issue, as inordinately burdened, considering the settlement offer together with the ripeness decision, of the governmental entity or entities. $^{46}$

Given the Act's unique, two-part definition of "inordinate burden," it is ambiguous how compensation is supposed to be calculated; in particular, it is debatable whether the level of compensation should differ depending on whether the claimant bases his claim on the alleged frustration of investment expectations or the alleged unreasonableness of his remaining uses.

To encourage settlement, the Act provides that a claimant who prevails in court may recover his reasonable attorneys fees and costs from the government, if the court determines that "the settlement offer, including the ripeness decision, of the governmental entity did not constitute a bona fide offer to the property owner which reasonably would have resolved the claim." ${ }^{47}$ On the other hand, a prevailing government defendant is also entitled to recover reasonable fees and costs from the property owner if the court determines that the owner declined a reasonable settlement offer. ${ }^{48}$

The final provision of the Bert Harris Act states, somewhat surprisingly, "This section does not affect the sovereign immunity of government." 49 On its face, this provision appears to bar claims for monetary relief from government, undercutting the purpose of the Act to create a new monetary remedy against government. While the meaning of this provision is grist for continuing debate, the Florida Third District Court of Appeals ruled that it should not be read to prohibit an award of monetary compensation. ${ }^{50}$

Nothing in the Bert Harris Act explicitly speaks to the rights of the public to participate in proceedings under the Act.

43 FLA. ST. ANN. $\$ 70.001(5)(a)$

44 FLA. ST. ANN. § 70.001(5)(b).

45 FLA. ST. ANN. § 70.001(6)(b).

46 FLA. ST. ANN. § 70.001(6)(b).

47 FLA. ST. ANN. § 70.001(6)(c).

48 Fla. ST. ANN. § 70.001(6)(c).

49 FLA. ST. ANN. § 70.001(13).

50 Royal World Metropolitan, Inc. v. City of Miami Beach, 863 So.2d 320 (Fla. Ct. App. 2003). 
The Dispute Resolution Act. The Dispute Resolution Act, which was adopted at the same time as the Bert Harris Act, grants regulated land owners a special opportunity to seek regulatory relief. Although the Act does not directly limit government authority or explicitly grant land owners new substantive rights, the Act puts a powerful thumb on the scales of public decision-making in favor of property owners. Unlike the Bert Harris Act, which only applies prospectively, the Dispute Resolution Act applies regardless of when the regulation was adopted.

A property owner who believes that a regulation "is unreasonable or unfairly burdens the use of the owner's real property" may initiate a proceeding under the Act by "fill[ing] a request for relief" with the government. ${ }^{51}$ The Act does not define the terms "unreasonable" or "unfair," though it seems clear, given the purpose of the Act to provide additional relief to regulated property owners, that they are not supposed to be equated with the constitutional takings test. The government is required to forward the request for relief to a special magistrate who is mutually acceptable to the government and the property owner. ${ }^{52}$

The government also must provide a copy of the request for relief to contiguous property owners and to "[a]ny substantially affected party" who substantively participated in the underlying administrative proceeding. ${ }^{53}$ These persons may request permission to participate in the proceeding, but participation "is limited to addressing issues raised regarding alternatives, variances, or other types of adjustment to the development order or enforcement action which may impact their substantial interests. " ${ }^{54}$ Moreover, the Act indicates that members of the public "shall not be granted party or intervenor status. " 55

The magistrate must hold a hearing on the request for relief, which must be "informal and open to the public." 56 The Act emphasizes that "[t]he object of the hearing is to focus attention on the impact of the governmental action giving rise to the request for relief," and to "explore alternatives" in terms of granting regulatory relief. ${ }^{57}$ The magistrate's primary responsibility is "to facilitate a resolution of the conflict" that addresses the claimant's concerns and reduces regulatory burdens. ${ }^{58}$

Following the hearing, the magistrate must prepare a written recommendation based on her findings, including any recommendations that the government "reduce[] restraints on the use of the owner's real property. " 59 The Act, unlike the Bert Harris Act, contains no provision addressing

\footnotetext{
51 Fla. ST. ANN. $§ 70.51(4)$.

52 Fla. ST. ANN. § 70.51(4).

53 FLA. ST. ANN. § 70.51(5).

54 FlA. ST. ANN. § 70.51(12).

55 FlA. ST. ANN. § 70.51(12).

56 FLA. ST. ANN. § 70.51(17).

57 FlA. ST. ANN. § 70.51(17).

58 FLA. ST. ANN. § 70.51(17)(a).

59 Fla. ST. ANN. § 70.51(19).
} 
potential conflicts between the outcome of the mediation process and established laws and regulations.

The government must respond to the magistrate's recommendation by accepting, modifying, or rejecting it. ${ }^{60}$ If the land owner and government agree on how to modify the restrictions, the government will proceed to implement the solution through the normal land use process. The Act states that a magistrate's recommendation is not sufficient, by itself, to amend a community's comprehensive plan, but the recommendation will be treated as "data in support of" such an amendment. ${ }^{61}$ Comprehensive plan amendments necessary to implement a magistrate's recommendation are exempt from the normal twice-a-year limit on plan amendments imposed by the Local Government Comprehensive Planning and Land Development Regulation Act. ${ }^{62}$

If the government rejects the magistrate's recommendations, or the parties are otherwise unable to agree, the government must issue "a written decision . . . that describes as specifically as possible the use or uses available to the subject real property. "63 In other words, even if the parties fail to arrive at a mutually acceptable solution, the government must record whether the mediation process has led the government to change its position. The magistrate's findings also "may serve as an indication of sufficient hardship to support modification, variances, or special exemptions, " 64 meaning that a magistrate's recommendation may provide the legal basis for challenging the government's failure to grant regulatory relief. This threat is obviously designed to encourage the government to accept the magistrate's recommendations and authorize development.

\section{The Consequences of the Florida Property Rights Legislation}

Our basic conclusion is that the Florida property rights legislation, and the Bert Harris Act in particular, has significantly altered the balance of power between developers and the public and made it virtually impossible for government to adopt and enforce new land use or environmental regulations. This conclusion closely tracks the findings of the only other recent, systematic assessment of the effects of the Florida property rights legislation, published in 2005, which concluded, among other things, that the Bert Harris Act has "tipp[ed] the balance in favor of land owners by freezing government regulatory activity after the date of the Act's inception," "f undamentally restricted [the ability of planners and attorneys] to do the[ir] job[s]," and created a general "regulatory chill" in the state. ${ }^{65}$ Even the eponymous sponsor of the Bert Harris Act has some reservations about the legislation; in a 2006 interview, Bert J. Harris, Jr. was quoted as stating

60 FLA. ST. ANN. $§ 70.51(21)$.

61 FLA. ST. ANN. $\$ 70.51(26)$. The procedures that must be followed to amend a comprehensive plan are set forth in FLA. ST. ANN. § 163.3184.

62 Fla. ST. ANN. § 70.51(26).

63 FLA. ST. ANN. § 70.51(22).

64 Fla. ST. ANN. § 70.51(25).

65 George Charles Homsy, The Land Use Planning Impacts of Moving "Partial Takings" from Political Theory to Legal Reality, 37 URB. LAW. 269, 286, 288 (2005). 
that "although the bill was designed to prevent government from indiscriminately engaging in actions just short of a 'taking' of a land owner's property, he never envisioned it as a development shelter." 66

Claims Data. According to records maintained by the Florida Department of Legal Affairs, as of February 2008, property owners had filed 202 Bert Harris Act claims with state, regional, and local governments, and property owners had filed 76 claims under the Dispute Resolution Act. Some indeterminate fraction of the Bert Harris Act claims subsequently evolved into full-blown litigation. It is doubtful that these data are completely accurate, ${ }^{67}$ but the Department's figures represent the best information available.

The number of claims filed in Florida over the past 13 years is significantly smaller than the number of claims filed under Oregon Measure 37 during the three years that that legislation was in effect. This disparity in numbers is mostly due to the fact that the Bert Harris Act, the more potent of the two parts of the Florida legislation, applies only prospectively; the vast majority of the thousands of claims filed under Measure 37 were based on regulations enacted prior to the measure's adoption. In addition, the smaller number of claims under the Bert Harris Act may be due to the fact that claimants must submit a "bona fide, valid appraisal" along with their requests for relief; the courts have said that failure to satisfy this condition mandates rejection of a claim. ${ }^{68}$ Measure 37 included no similar requirement.

More importantly, however, the number of claims and lawsuits filed in Florida provides only limited insight into the impact of the property rights legislation. As discussed below, some communities have decided against adopting new regulations because of the prospect of claims, and other communities have withdrawn or relaxed regulations in the face of threats that Bert Harris Act claims would be filed. These impacts appear to be by far the most significant consequence of the Bert Harris Act.

Litigation Activity. Developers have filed a sufficient number of successful lawsuits under the Act to confirm the expansiveness of the inordinate burden test. Several developers have succeeded in obtaining financial recoveries under the Act, albeit typically through a settlement after filing a lawsuit demanding compensation. In Aquaport, L.C. v. Collier County, following the developer's filing of an application with Collier County to construct a 10-story, 68-unit hotel, the County amended its development code to limit density, forcing the developer to build a smaller 15unit condominium. The Circuit Court ruled that the amendment constituted an inordinate burden,

\footnotetext{
${ }^{66}$ Mitchell Pellachia, Bert J. Harris Act Looms over Alaska Parcel Concessions, MiAmi Sun Post, July 21, 2006.

67 For example, Hillsborough County has had a total of 23 Dispute Resolution Act cases, but the state database indicates the County has had only 7 cases. Interview with Paula Harvey, Director, Hillsborough County Planning \& Zoning Division, in Tampa, Florida, Feb. 20, 2008.

68 See, e.g., Osceola County v. Best Diversified, Inc, 936 So.2d 55 (Fla. Ct. App. 2006).
} 
and the County settled the case by paying the developer $\$ 2.75$ million. ${ }^{69}$ In another case, the City of Miami Beach reportedly settled a Bert Harris Act claim based on a reduced floor area restriction by purchasing the property, which was adjacent to city hall, for municipal use. ${ }^{70}$ Significantly, apparently no Florida court, at any level, has rejected a claim under the Act on the ground that the regulation was not sufficiently burdensome to rise to the level of an inordinate burden.

Despite these litigation successes, there has been, as one commentary observes, an "unanticipated dearth of litigation" under the Act. ${ }^{71}$ All told, the Bert Harris Act has probably generated fewer than several dozen lawsuits since its adoption. Even more remarkable, the appellate courts have issued almost no decisions providing guidance on how to interpret the Act. The Florida Supreme Court has declined every opportunity to hear a case involving a Bert Harris Act claim, ${ }^{72}$ and the Courts of Appeals have issued only a handful of reported decisions. As to the inordinate burden standard, the Fifth District Court of Appeals has observed that the Bert Harris Act "creates a separate and distinct cause of action for property owners where governmental regulation has 'inordinately burdened' the property, but does not amount to a 'taking' under the Florida or federal constitutions. "73 In that case the Court affirmed rejection of a claim based on Marion County's refusal to extend the term of a permit authorizing operation of a waste disposal facility, reasoning that since the owner's permit to operate the facility was originally time limited, the owner lacked the investment-backed expectations necessary to support a claim. ${ }^{74}$ But, beyond this, the Courts of Appeals have said essentially nothing about how to determine when the Act requires payment of compensation. $^{75}$

${ }^{69}$ Ronald L. Weaver \& Joni Armstrong Coffey, Private Property Rights Protection LEGISLATION: STATUTORY ClAiMS FOR RELIEF FROM GOVERNMENTAL REGULATION 14 (Fla. Bar 2007).

70 Homsy, Land Use Planning Impacts, 37 URB. LAW. at 289.

71 Weaver \& Coffey, PRIVATE PROPERTY Rights PROTECTION LEGISLATION 43.

72 See Brevard County v. Stack, 949 So. $2 d 197$ (Fla. 2007) (denying review); Palm Beach Polo, Inc. v. Village of Wellington, 929 So.2d 1053 (Fla. 2006) (denying review); City of Miami Beach $v$. Royal World Metropolitan, Inc., 895 So.2d 404 (Fla. 2005) (denying review).

73 Holmes v. Marion County, 960 So.2d 828, 829 (Fla. Ct. App. 2007) (quoting Osceola County, 936 So. 2 d at 58 n. 3).

74 Holmes, 960 So. 2 d at 829.

75 The other reported appellate decisions under the Act have dealt with collateral issues such as whether the regulated activity represented a nuisance, see Osceola County, 936 So. $2 \mathrm{~d}$ at 60 n. 5 , whether the claim for relief was accompanied by a bona fide, valid appraisal, see id., whether the restriction was based on a pre-1995 law, see Palm Beach Polo, 918 So.2d 988, and whether the claimant met the schedule governing prosecution of Bert Harris Act claims. See Russo Ass'n, Inc v. City of Dania Beach Code Enforcement Board, 920 So.2d 716 (Fla. Ct. App. 2006); Sosa v. City of West Palm Beach, 762 So.2d 981 (Fla. Ct. App. 2000). See also Osceola County, 830 So.2d 139 (striking down provision of the Bert Harris Act that authorized an interlocutory appeal from a trial court finding that a government action resulted in an inordinate burden). In response to this decision, the Supreme Court adopted FLA. R. APP. P. 9.130(a)(3)(c) allowing such interlocutory appeals. See Amendments to Florida Rules of Civil Procedure, 894 So. 2d 202 (Fla. 2005). 
What explains this small volume of litigation and the lack of appellate court guidance? There are several plausible, overlapping explanations. The Act's chilling effect has undoubtedly derailed regulatory initiatives that would have produced litigation if they had been implemented. The numerous unanswered questions about the Act may make potential claimants reluctant to invest the time and money to litigate claims. The Act's provision awarding attorneys fees and costs to a prevailing party may have created an additional disincentive for litigation. The Florida courts also may be reluctant to grapple with the challenge of developing a new statutory doctrine of regulatory takings that is vaguely related to the constitutional doctrine yet different and more protective of property rights. Finally, the Florida courts, which probably have some institutional commitment to the established constitutional takings standard, ${ }^{76}$ may be reluctant to acknowledge how dramatically the legislature has transformed property rights protection in Florida.

An ironic, unfortunate and no doubt unintended consequence of the lack of judicial engagement with the Act is that it has increased the burden the Act imposes on the state and local governments. As one commentator has observed, "The level of uncertainty about the meaning of the Act leaves a wide playing field for litigants to advance an interpretation that favors them." 77 This uncertainty has increased the litigation risks to governments facing claims, which in turn has increased the Act's chilling effect, the topic to which we now turn.

The Regulatory Chill. In the absence of significant litigation, the primary effect of the Act has been to discourage governments from adopting new regulatory restrictions. There are two kinds of evidence for this chilling effect: examples of regulatory proposals that communities put forward and later abandoned in the face of a threat that the regulation might generate Bert Harris Act claims, and direct assertions by public officials that such a chilling effect exists.

For example, one Florida city reportedly hired a consultant to prepare a historic preservation ordinance but decided against adopting the ordinance upon advice from the City Attorney that it would likely expose the city to suit under the Bert Harris Act. ${ }^{78}$ Similarly, Palm Beach County abandoned plans to reduce the permitted intensity of development in a 20,500-acre agricultural reserve east of the Everglades based on legal advice that the additional restrictions could trigger claims under the Act. ${ }^{79}$ In another example, Fort Lauderdale proposed to rewrite its zoning code to create transitional zones between residential and commercial areas but, according to a former

\footnotetext{
76 In one leading Florida takings case, Graham v. Estuary Properties, Inc., 399 So. 2d 1374 (Fla. 1981), the Florida Supreme Court rejected a taking claim based on a development order that required the owner to retain half of the property (a large mangrove forest) in its natural condition. The adoption of this type of regulatory restriction would almost certainly constitute an inordinate burden under the Bert Harris Act.

77 Susan L. Trevarthen, Advising the Client Regarding Protection of Property Right-Harris Act and Inverse Condemnation Claims, 78-AUG. FLA. BAR J. 61, 64 (July/Aug. 2004).

78 Hunt, Property Rights and Wrongs, 48 FLA. L. REV. at 718 n 57.

79 George Bennett, New Law Foils Plan to Cut Ag Reserve Development, PALM Beach Post, May 25,1995 .
} 
planner for the City, "With Bert Harris, we just aborted that." 80 It is likely that these examples are representative of a broader pattern, but absent a systematic survey it is impossible to know the full extent of the chilling effect.

Various public statements by local officials and government attorneys also support the conclusion that the chilling effect is real. Tim Jones, Deputy Assistant County Attorney for Lee County acknowledged that the Bert Harris Act "sometimes affects the way public officials in Lee County and elsewhere make zoning decisions. " 81 He explained that "[e]lected officials have been reluctant to pass laws that could expose them someday to the Bert Harris Act." 82 Similarly, George Forbes, Jacksonville Beach City Manager, stated that the Act "has a chilling effect because government officials are afraid the city will be liable to the property owners who can claim that a denial of their permit will reduce their property's fair market value and entitle them to compensation." 83 David Dermer, the Mayor of Miami Beach, said that "Commissioners have used the Harris Act as an excuse to shy away from zoning changes," ${ }^{84}$ and that threats of "[m]illions and millions of dollars have been used as a hammer by the development community" to obtain approval of development projects. ${ }^{85}$ In the same vein, David Jordan, Deputy General Counsel for Florida's Department of Community Affairs, stated "I think the chilling effect has been the major impact" of the Bert Harris Act and that "Governments have been wary of the law so they have tended not to make any changes." 86 Again, absent a statewide survey it is difficult to know how widespread this sentiment is. But these public statements certainly suggest a common viewpoint on the issue among government attorneys and other officials.

Developers and their attorneys essentially view the Bert Harris Act in the same light. Chuck Mitchell, a Tallahassee developer, observed that the Bert Harris Act gave developers "a mechanism to get government's attention." 87 He stated that the Bert Harris Act was "all he needed" to get one development project approved. ${ }^{88}$ Threats of Bert Harris Act claims have become a regular part of the real estate business in Florida. ${ }^{89}$ Developers' attorneys describe how they routinely raise the

${ }^{80}$ Homsey, Land Use Planning Impacts, 37 URB. LAW. at 290.

81 Don Ruane, Lee Blasted in Claim Over Digging Rights, NEWs-PRESS, June 11, 2003.

${ }^{82} I d$.

83 Caren Burmeister, Council Opposes Property Act Change Amendment Would Make It Retroactive, Florida TIMES-UnION, Mar. 19, 2003.

${ }^{84}$ Nicole White, Miami Beach, Fla., Wins Zoning Case; Officials Call Decision Pivotal, MiAmI HERALD, Aug. 4, 2002.

${ }^{85} I d$.

86 Dave Hogan, Mapping Out Land Compensation, OREgONIAN, Mar. 12, 2001.

87 Geri Throne, A Real Balancing Act, ORLANDO SENTINEL, Apr. 18, 1999.

$88 \mathrm{Id}$.

89 See, e.g., Judy Berman, Challenges likely to new restrictions, FLORIDA TODAY, Dec. 30, 2002 (describing threats of Bert Harris Act claims against the City of Cocoa Beach after it imposed height and density limits, down-zoned certain commercial properties, and imposed a temporary building moratorium); Drew Dixon, Property Owner Says it is suing city over Wal-Mart; The 
specter of Bert Harris Act liability when speaking with government officials about land use issues. One attorney reported that he had threatened to assert Bert Harris Act claims "hundreds of times." 90

This evidence, albeit anecdotal, suggests that the primary effect of the Bert Harris Act has been to stop governments, particularly at the local level, from adopting new laws and regulations that they likely would have adopted in the Act's absence. The ultimate effect has been to undermine the capacity of Florida's democratic institutions to respond to the will of the public, and to reduce the protections for land and other natural resources that Floridians would otherwise enjoy. While Florida has experienced torrid growth for many decades, the Act made it more difficult for the public to manage growth and mitigate its consequences.

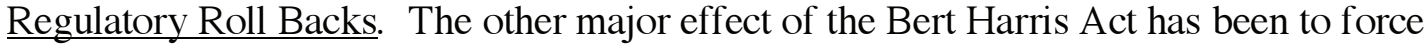
communities to rescind or relax regulations in the face of specific Bert Harris Act claims or threats of such claims. Thus, even when communities have been able to overcome the Act's chilling effect and adopt new regulations, they have often been forced to roll back the restrictions after the fact. Some examples include:

- In June 2007, the Fort Lauderdale City Commission granted a historic designation to Stranahan House, a century-old house built by city pioneers Frank and Ivy Stranahan. A few months later, the City's Historic Preservation Board relied on the designation to deny a certificate of appropriateness for a planned 38-unit condominium project on an adjacent property. The developer responded by demanding \$120 million in compensation under the Bert Harris Act and on other grounds. Attorneys for the developer publicly stated that the claim was not a threat but rather a "reminder of consequences," ${ }^{91}$ and fliers were mailed to city residents depicting a gambler's roulette wheel and reading: "The city of Fort Lauderdale can't risk a $\$ 120$ million bet." 92 On appeal, the City Commission voted 3 to 2 to overturn the Historic Preservation Board, relying on advice from the City Attorney that rejecting the development application would have "serious negative

company had planned to lease its site to the retailer, FLORIDA TIMES-UNION, Oct. 11, 2006 (describing a threat of a Bert Harris Act claim by owner of a proposed Wal-Mart site). 90 Interview with Clifford A. Schulman, Partner, Greenberg Traurig, LLP, in Miami, Florida, Mar. 14, 2008.

${ }_{91}$ Brittany Wallman, Condo developer might seek damages from Fort Lauderdale: Stalled for nearly a decade, Builders of Icon condo await city action, SOUTH FLORIDA SUN-SENTINEL, Sept. 27, 2007.

${ }^{92}$ Brittany Wallman, Fort Lauderdale OKs 42-story condo next to Stranahan House, SOUTH FLORIDA SUN-SENTINEL, Oct. 3, 2007. 
consequences for the city, primarily in the form of monetary damages. "93 The developer has announced: "When completed, Icon Las Olas is planned to reach a height of 455 feet, taller than any other projects completed in the downtown area, making it the tallest building in Fort Lauderdale." 94

- The voters of the City of West Palm Beach adopted a referendum decreasing the maximum permitted building height in the city from 15 stories to 5 stories, prompting the filing of several Bert Harris Act claims. One developer, in anticipation of the new height restrictions, filed an application to develop two 15story buildings and a 6-story parking garage. After the referendum was enacted, the City denied the application. The developer filed suit, and the Circuit Court ruled that the City was liable, rejecting the City's argument that the voters' approval of the referendum could not be ascribed to the City. The City settled the case, permitting the developer to construct the two 15-story buildings, although the developer agreed to abandon the proposed 6-story parking garage. ${ }^{95}$

- In a long-running dispute involving the Portofino project on the southern tip of Miami Beach, the owner sued the City under the Bert Harris Act for $\$ 15$ million after the City down-zoned the property, reducing the permitted square footage of development. The City eventually settled, permitting development of the property with a square footage almost $40 \%$ in excess of what the zoning regulation allowed. ${ }^{96}$

- In 2004, voters in Jacksonville Beach adopted a referendum imposing a 35-foot height cap on oceanfront development. Southern Waterview, a developer that planned to build a 10-story oceanfront condominium, filed a \$38 million Bert Harris Act claim, asserting that the new regulation interfered with its vested right to proceed with the project, based on the fact that it had filed its building plans with the City on November 1, 2004, a few days before the election. Following the advice of the City Attorney that the developer had a potentially meritorious Bert Harris Act claim, the

93 Id.

94 Remax Beach Properties, Press Release, Icon Las Olas Fort Lauderdale Preconstruction Real Estate Condos, July 28, 2007, available at http://openpr.com/news/3298/ICON-Las-Olas-FortLauderdale-Preconstruction-Real-Estate-Condos. html.

${ }_{95}$ Fidelity Fed. Sav. Bank. v. City of West Palm Beach, BH-97-50-02, Cir. Ct. Case No. CL-971470-AE (Fla. 15th Jud. Cir. 1997); Homsey, Land Use Planning Impacts, 37 URB. LAW. at 289; Ronald L. Weaver \& Elizabeth Ynigo, Florida's Bert Harris Private Property Rights Protection Act-An Owner's Bridge Too Far? (Stearns Weaver 2005).

96 Ronald L. Weaver, Bert Harris Update 2007, CLE International_Litigating Land Use (2007). 
City allowed the developer to proceed with the project in violation of the new height cap. $^{97}$

- In 2003, Citrus County eliminated mixed-use coastal zoning in a portion of the community in favor of low density residential development. A developer, W.W. Carthur, Jr., filed a $\$ 730,000$ Bert Harris Act claim, and the City settled the claim by allowing the construction of a 50-unit waterfront subdivision with 35 boat docks. In addition to being contrary to the amended zoning regulation, the development violated the County's land use plan because it was within 5 miles of a nuclear power plant. $^{98}$

- In Martin County, a developer filed a \$1.6 million Bert Harris Act claim based on wetlands regulations, and the County settled the dispute by allowing the developer to construct 150 luxury homes on the property, together with 155 boat docks and a 54slip commercial marina. ${ }^{99}$

- In Collier County, after the County denied a developer permission to construct a 111-acre golf course and resort within 35 feet of an active bald eagle nest site, the developer filed a claim under the Bert Harris Act demanding \$285 million in compensation. The County eventually settled by allowing the development to proceed in exchange for several commitments from the developer, including an agreement to construct an artificial tree, located offsite, designed to attract the eagles. County Commissioner Frank Halas was quoted as saying he "didn't want to make a deal, but feared that the county could lose the lawsuit." 100

- In Bartow, after the City Council denied an application for a variance to construct a 272-acre housing development, the developer filed a \$9.34 million Bert Harris Act claim. The City Attorney advised the City that it faced potential liability under the Act on the ground that the proposed development was consistent with the City's comprehensive plan. Based on this advice, a 3-2 majority of the City Council approved a modified version of the project allowing the housing development to proceed. One of the commissioners objected that by approving the development the City "set[] a preceden[t] that we are going to let the developers rule with threats of

\footnotetext{
97 Caren Burmeister, City struck deal with developer, records say; Southern Waterview wants to exceed the building height limit, FLORIDA TIMES-UNION, Mar. 3, 2007.

98 Jorge Sanchez, Housing project suit ends with deal, ST. PETERSBURG TIMES, Jan. 12, 2006; Catherine E. Choichet, County: Not So Fast on Lawsuit Settlement, St PeTERsBurg Times, Nov. 9, 2005; Catherine E. Choichet, Commissioner Rues Vote on Suit, St PETERsburg Times, Nov. 8, 2005.

99 Homsey, Land Use Planning Impacts, 37 URB. LAW. at 289.

100 Andrea Stetson, Developer buys condo rights near eagle nest; Collier is paid \$6 million, NEWS-PRESS, Sept. 1, 2006.
} 


\section{Texas}

In 1995, after extensive debate, the Texas legislature passed and then Governor George W. Bush signed into law the Private Real Property Rights Preservation Act. ${ }^{\mathrm{a}}$ The legislation is both complex and relatively limited in scope, which probably explains why property owners have rarely invoked the Act and why legal claims based on the Act have seldom if ever succeeded. Indeed, over the thirteen years since it was adopted, there has been no reported court decision granting compensation or other relief under the Act. It is less clear, especially in light of the pro-property rights culture in Texas, what if any chilling effect the Act may be having.

The Act defines a "taking" as a government action that is "the producing cause of a reduction of at least 25 percent in the market value of the affected property." b But, as a result of several large carve outs, the Act generally does not apply to actions by municipalities, ${ }^{c}$ and also exempts actions "reasonably taken" to comply with federal or state legal mandates. ${ }^{\text {d }}$ The Act also includes the familiar exemptions for regulations addressing nuisances and threats to public health and safety, as well as a hodge-podge of other exemptions relating to, for example, oil and gas development, hunting and fishing, floodplains, groundwater, land subsidence, and taxation. ${ }^{\mathrm{e}}$

In a variation on the usual pay or waive formulation, the default remedy under the Act is an injunction barring enforcement of the regulation. ${ }^{f}$ However, the government defendant has the option of paying the "damages as compensation" and keeping the offending regulation in place. ${ }^{\mathrm{g}}$. In an odd twist, because the Act's definition of government actions giving rise to a taking is not restricted to actions limiting the use of property, a persuasive case can be made that the Act applies to government authorization of development activity that reduces the value of neighboring properties by $25 \%$ or more. ${ }^{\mathrm{h}}$

The Act also requires governmental entities to prepare "Takings Impact Assessments" (TIA) prior to undertaking an action that "may result in a taking" within the meaning of the Act. ${ }^{\mathrm{i}}$ A private property owner affected by a governmental action that should have been, but was not analyzed in a TIA, can sue to invalidate the government action. ${ }^{j}$

a TEX. GOV'T CODE $\S \S 2007.001-2007.045$.

b TEX. GOV'T CODE $\S 2007.002(5)(B)(i i)$. Property under the Act means private "real property recognized by common law, including a groundwater or surface water right of any kind." Id. at § 2007.002(4).

c TEX. GOV'T CODE $§ 2007.003(b)(1)$. The Act applies to a municipal action only in the case of an action "that has effect in the extraterritorial jurisdiction of the municipality, excusing annexation, and that enacts or enforces an ordinance, rule, regulation, or plan that does not impose identical requirements or restrictions in the entire extraterritorial jurisdiction of the municipality." Id. at $\$ 2007.003(a)(3)$.

d TEX. GOV’T CODE $\S 2007.003(b)(4)$.

e TEX. GOV'T CODE $\$ 2007.003(b)$.

f TEX. GOV'T CODE $\$ 2007.024(a)$.

g TEX. GOV'T CODE $\$$ 2007.024(c).

h Cf. Wilkinson v. Dallas/Fort Worth International Airport Board, 54 S. W.3d 1, 18 (Tex. Ct. App. 2001) (affirming, on procedural grounds, dismissal of homeowners' claims under the Act alleging that the value of their property was reduced by a runway expansion project). i TEX. GOV'T CODE $§ 2007.043$.

j TEX. GOV'T CODE $§ 2007.044$. 
In the handful of reported cases involving alleged takings under the Act, the claims have been dismissed for lack of standing, ${ }^{\mathrm{k}}$ on the ground that the government action was "reasonably taken" to comply with state law, and on other, narrow procedural grounds." In another instance the Court of Appeals of Texas, reversing the trial court's rejection of a taking claim on a motion for summary judgment, ruled that there were disputed issues of fact concerning whether the government action was covered by one of the Act's exemptions. $^{\mathrm{n}}$ There is no record of a final, definitive ruling that either invalidates a government action or awards compensation under the Act.

In the other reported cases under the Act, the courts rejected claims that agencies violated the Act by not preparing TIAs. ${ }^{\circ}$ One analysis conducted by the Texas Comptroller the year after the Act was passed concluded that four of the 131 state agencies that the Comptroller surveyed prepared TIAs. ${ }^{\mathrm{p}}$ There is no database of the number of TIAs prepared since, but our research indicates that, at a minimum, state agencies have recognized that the Act requires the preparation of TIAs and generally prepare them as required. ${ }^{q}$

${ }^{\mathrm{k}}$ Chambers County v. TSP Development, Ltd., 63 S. W.3d 835, 837-38, 840 (Tex. Ct. App. 2001) (developer with option contract for real property did not possess a property interest sufficient to support standing to sue under the Act).

${ }^{1}$ McMillan v Northwest Harris County Mun. Util. Dist. No. 24, 988 S. W.2d 337, 340 (Tex. Ct. App. 1999) (levy of delinquent standby fees by utility district not a taking under the Act because "the levy was an action of a political subdivision that was reasonably taken to fulfill an obligation mandated by state law").

m Wilkinson, 54 S. W.3d at 18 (rejecting the argument that trial court erred in granting summary judgment for the government when the plaintiff ostensibly withdrew the taking claim, on the ground that the plaintiff failed to provide legal support for the appeal point).

n South West Property Trust, Inc. v. Dallas County Flood Control Dist. No. 1, 136

S. W.3d 1, 10-11 (Tex. Ct. App. 2001) (vacating and remanding judgment for flood control district because there were disputed issues as to whether a tax was mandated by state law).

o Bragg v Edwards Aquifer Authority, 71 S. W.3d 729, 737 (Tex. 2002) (State agency's adoption of well-permitting rules did not require the preparation of TIA because the action fell within Act's exemption for actions taken to "prevent waste or to protect the rights of owners of interest in groundwater."); Duncan v. Calhoun County Navigation District, 28 S. W.3d. 707, 711-12 (Tex. Ct. App. 2000) (TIA requirement did not apply to government decision about whether to exercise eminent domain, because eminent domain is expressly exempted from the Act).

p See Marcilynn A. Burke, Much Ado About Nothing: Kelo v. City of New London, Babbitt v. Sweet Home, and Other Tales from the Supreme Court, 75 U. CIN. L. REV. 663, 680 (2006) (citing John Sharp, Texas Comptroller of Public Accounts, Report on the Private Real Property Preservation Act, (Senate Bill 14) 1, 6 (1997)).

${ }^{q}$ See, e.g., TEX. ADMIN. CODE Title 4, Part 1, Chapter 1(A), Rule $\S 1.41$, available at $<\mathrm{http}$ //secure. sos. state.tx. us/pls/pub/readtac\$ext.TacPage?sl=R\&app=9\&p_dir=\&p_rloc= $\& p \_t l o c=\& p \_p l o c=\& p g=1 \& p \_t a c=\& t i=4 \& p t=1 \& \mathrm{ch}=1 \& \mathrm{rl}=41>($ for an example of an agency's TIA regulation); Texas Association of Counties, Exemption from takings law requires immediate, COUNTY ISSUES, Apr. 1997, available at $<$ http://www.county.org/resources/library/cissue/LN/vol7no12/Record714216.html> (discussing costs imposed on Harris County by the TIA requirement); Texas Commission on Environmental Quality, Proposed Regulations Chapter 290 - Public Drinking Water Rule Project No. 2006-045-290-PR, at 115-117, available at $<$ http://www.tceq. state.tx. us/assets/public/legal/rules/rule_lib/proposals/06045290_pro_clea n. pdf $>$ (for an example of a TIA). 
lawsuits," and that the City would "be intimidated with threats of lawsuits if we do not approve zoning or whatever it is they want." 101 Disappointed with this aboutface, a citizen group called the "Enough Already Committee" mounted a referendum petition to overturn the City Council's action and subsequently sued the City for failing to respond to the group's petition. As of April 2008, the litigation was still pending. ${ }^{102}$

While these appear to be the most significant examples in which developers used the Bert Harris Act to force communities to roll back regulations, this list is by no means exhaustive. Yet just this handful of cases, many of which were covered extensively in local newspapers, undoubtedly sent a powerful message to communities considering adopting new regulations and reinforced the Act's chilling effect.

The Dispute Resolution Act. There is comparatively little evidence about the effects of the Dispute Resolution Act, largely because the Act is designed to encourage informal resolution of property owners' complaints about regulatory burdens and does not create judicially enforceable legal rights. Nonetheless, our examination of the experience of Hillsborough County suggests that the Act significantly benefits developers at the expense of the broader community. Twenty three Dispute Resolution Act claims have been filed with the County since the Act's adoption. In twelve of these cases, or more than $50 \%$, the County reversed its initial rejection of the development application and approved the project in some modified form. Even discounting for the probability that claimants who pursued this process were relatively likely to have sympathetic cases, these data suggest that the Dispute Resolution Act provides a significant avenue for obtaining regulatory relief. One county official described citizens' common frustration and surprise when they learned, after the completion of the normal regulatory review process, that the Dispute Resolution Act granted developers a one-sided opportunity to take another bite at the proverbial apple. ${ }^{103}$

101 Petition for Writ of Mandamus and Memorandum of Law at Exhibit C: Minutes, Bartow City Commission, Regular Meeting, Monday, Nov. 5, 2007, Pfeiffer v. City of Bartow (Fla. 10th Jud. Cir. Ct.).

102 Suzie Schottelkotte, Bartow faces key vote on project, LEDGER, Sept. 2, 2007; Metro, Commission OKs controversial development, LEDGER, Sept. 5, 2007; Suzie Schottelkotte, Legal Threat Comes From New Direction: Approval of Large Housing Development Brings Challenge From Projects Neighbor: Bartow Commission, LEDGER, Sept. 6, 2007; Suzie Schottelkotte, Bartow Residents Launch Petition Drive; They Want to Force A Referendum on the Proposed Wind Meadows Project, LEDGER, Sept. 16, 2007; Suzie Schottelkotte, Bartow residents get a voice in lawsuit over housing development, LEDGER, Oct. 28, 2007.

103 Interview with Paula Harvey, Director, Hillsborough County Planning \& Zoning Division, in Tampa, Florida, Feb. 20, 2008. The Dispute Resolution Act has generated even less reported case law than the Bert Harris Act, and it has been largely procedural in nature. See Peninsular Prop. Braden River, LLC v. City of Bradenton, 965 So.2d 160 (Fla. Ct. App. 2007) (rejecting constitutional challenge to the Act's provision tolling the jurisdictional time limit for filing judicial challenges to agency administrative orders); Hanna v. Environmental Protection Commission, 735 So.2d 544 (Fla. Ct. App. 1999) (holding that a letter accompanied by a scientist's field report 


\section{What Comes Next?}

The politics of land use in Florida bring to mind the image of two locomotives on a single track racing toward a collision. One locomotive is the Bert Harris Act, which appears to be gaining considerable momentum after 13 years as communities settle claims for millions of dollars or, much more commonly, forego adopting new regulations or abandon newly adopted regulations. In some quarters, political support for the property rights agenda remains strong; virtually every year bills are introduced in the Florida legislature to clarify and strengthen the Bert Harris Act. ${ }^{104}$ Despite the Act's chilling effect on government's capacity to regulate, so far there has been little if any public discussion about limiting the scope of the Act.

The other locomotive is the Florida Hometown Democracy movement, a grassroots effort to promote greater citizen participation in and control over the land use regulatory process. ${ }^{105}$ The supporters of Hometown Democracy propose to place a constitutional amendment on the 2010 state ballot that would require voter approval for any change to a local government's comprehensive plan. ${ }^{106}$ The driving force behind this effort is the perception that the public has been excluded from meaningful participation in the development review process and that close collaboration between developers and local officials has produced pro-developer land use decisions. ${ }^{107}$ According to the Hometown Democracy website: "Citizens in a community have rights, too. We have the right to demand that our 'quality of life' not be harmed by endless construction. ... Our elected officials take an oath to protect the public interest. But too many county and city commissioners just cannot say no to comprehensive plan amendments that are destructive to a community's well being." 108

The property rights legislation and the Hometown Democracy movement are on a collision course in the sense that Hometown Democracy is partly a reaction to the fall out from the property

indicating that parcel might contain wetlands was not a development order triggering the Act's dispute resolution process); Scott v. Polk County, 793 So.2d 85 (Fla. Ct. App. 2001) (holding that Circuit Court lacked jurisdiction to enjoin special master proceeding under the Act).

104 See Trevarthen, Advising the Client, 78-AUg. FLA. BAR J. at 64. In the 2008 legislative session, one bill would have redefined the regulations subject to the inordinate burden standard to include development moratoria, reduced the waiting period before claimants could go to court, and clarified that the enactment (as opposed to the application) of a new law or regulation does not trigger the limitations period for filing claims. H.B. 881 (2008). This amendment failed to pass.

105 Florida Hometown Democracy, About Us, at http://www.floridahometown democracy.com/about.html.

106 Florida Hometown Democracy, Petition, at http://www.floridahometowndemocracy. com/documents/FHD_Petition2-Final.pdf. See also Dan Dewitt, Decision on Development Worth Revisiting, St PETERsBURG Times, Apr. 28, 2008.

107 Patrick Slevin, No: Let's update meeting Protocol and heal trust in local government, TC PALM, July 24, 2007, at http://www.tcpalm.com/news/2007/jul/24/con-florida-hometowndemocracys-citizen-initiative/.

${ }^{108}$ Florida Hometown Democracy, About Us, at http://www.floridahometowndemocracy. com/about. html. 
rights legislation. The basic purpose of the property rights legislation was to give developers more leverage in their dealings with government officials while limiting public involvement in the resolution of the claims. Viewed in historical context, the Hometown Democracy movement appears to represent an understandable and not entirely unreasonable grassroots reaction to the success of the property rights movement in Florida.

A more specific risk of a conflict arises from the fact that local communities sometimes have to adopt comprehensive plan amendments to implement settlements of claims under the Bert Harris or Dispute Resolution Acts. ${ }^{109}$ Under the Hometown Democracy proposal, voters could veto these amendments, with the result that governments threatened with expensive claims might find themselves blocked from making settlements. Hometown Democracy, piled on top of the property rights legislation, threatens to produce a massive, and massively expensive, regulatory gridlock.

The Florida property rights legislation is plainly one of the root causes of the citizen frustration driving the Hometown Democracy movement. Rather than pursue an agenda that threatens the state with gridlock, supporters of the Hometown Democracy agenda, as well as those sympathetic to the concerns driving this movement, might consider addressing the frustrations with Florida's land use policies more directly by seeking the reform, if not the repeal, of the property rights legislation itself.

109 See FlA. ST. ANN. § 163.3194(1)(a) ("After a comprehensive plan, or element or portion thereof, has been adopted in conformity with this act, all development undertaken by, and all actions taken in regard to development orders by, governmental agencies in regard to land covered by such plan or element shall be consistent with such plan or element as adopted."). 


\section{Oregon Property Rights Legislation}

\section{Introduction}

On November 2, 2004, Oregon voters, by a margin of $61 \%$ to 39\%, adopted Measure 37, a ballot title that read, "Government must pay owners or forgo enforcement, when certain land use restrictions reduce property value." 110 The measure revolutionized property rights and the land use regulatory process in Oregon and unleashed a heated public debate about the takings issue, culminating three years later in another successful ballot measure (Measure 49) that substantially narrowed Measure 37.

The contest over Measure 37 was in large part a battle over the consequences and future viability of Oregon's well-known land use program. Created under the leadership of Governor Tom McCall in the 1970's, the program established a Department of Land Conservation and Development (DLCD), led by a Land Conservation and Development Commission (LCDC). ${ }^{11}$ The LCDC was charged with establishing a set of state land use policy goals, which included a mandate for extensive public involvement in the land use program, ${ }^{112}$ a requirement that local governments establish urban growth boundaries " $[\mathrm{t}$ ]o provide for an orderly and efficient transition from rural to urban land use," 113 and policies for the preservation of millions of acres of forest and agricultural lands for commercial farm and timber production. ${ }^{114}$ Local communities are required to prepare and regularly update local plans and regulations to conform to the state goals, a process overseen by the DLCD. ${ }^{115}$ In 1979, the legislature established a three-member Land Use Board of

110 Oregon Office of the Sec'y of State, Certified Ballot Title for Measure 37 (Apr. 22, 2003), available at http://www. sos. state. or. us/elections/irr/2004/036cbt. pdf; Oregon Sec'y of State, General Election Abstract of Votes on State Measure No. 37 (Nov. 2, 2004), available at $\mathrm{http} /$ www. sos. state. or. us/elections/nov2204/abstract/m37. pdf. In 2000, Oregon voters adopted Measure 7, a similar measure amending the Oregon Constitution, which was struck down by the Oregon Supreme Court on the ground that it violated the "single subject" rule. See McPherson v. Dep’t of Admin. Servs., 130 P.3d 308, 312 (Or. 2006).

111 Carl Abbott \& Deborah Howe, The Politics of Land Use Law in Oregon: Senate Bill 100, Twenty Years After, 94 OR. HIST. Q. 5 (1993); Edward J. Sullivan, Remarks to University of Oregon Symposium Marking the Twenty-Fifth Anniversary of SB 100, 77 OR. L. REV. 813 (1999).

112 Oregon's Statewide Planning Goals \& Guidelines, Goal 1: Citizen Involvement, codified at OR. ADMIN. CODE $§ 660-015-0000$, available at http://www.lcd.state. or.us/LCD/docs/goals/goal1.pdf.

${ }_{113}$ Oregon's Statewide Planning Goals \& Guidelines, Goal 14: Urbanization, codified at OR. ADMIN. CODE § 660-015-0000, available at http://www.lcd. state. or. us/LCD/ docs/goals/goal14.pdf.

114 Oregon's Statewide Planning Goals \& Guidelines, Goal 3: Agricultural Lands, codified at OR. ADMIN. CODE $§$ 660-015-0000, available at http://www.lcd. state.or.us/

LCD/docs/goals/goal3.pdf; Oregon's Statewide Planning Goals \& Guidelines, Goal 4: Forest Lands, codified at OR. ADMIN. CODE $§$ 660-015-0000, available at http://www.lcd. state. or. us/LCD/docs/goals/goal4.pdf. See also OR. REv. ST. § 197.180; OR. REV. ST. § 195.020.

115 Oregon's Statewide Planning Goals \& Guidelines, Goal 2: Land Use Planning, codified at OR. ADMIN. CODE $§$ 660-015-0000, available at http://www.lcd. 
Appeals to hear appeals from local land use disputes. ${ }^{116}$ Generally speaking, in comparison with Florida's land use program, the Oregon program is more prescriptive about what land uses are permitted where.

The Oregon land use program has been both very popular within the state and a source of continuous public controversy. ${ }^{117}$ Several ballot measures have been presented to the voters to dilute the program, producing hard fought political contests, but none was ultimately successful. ${ }^{118}$ The Oregon legislature has repeatedly debated the program and from time to time adopted amendments that have modestly weakened the original vision of Governor McCall and his allies and also made the program a good deal more complex and confusing to the public. ${ }^{119}$ Nonetheless, the basic structure of the program adopted in the 1970s remains in place today.

The campaign on behalf of Measure 37 was led by Oregonians in Action (OIA), an effective property rights organization founded in large measure to counter-balance 1000 Friends of Oregon, the advocacy group founded by Governor McCall to support the Oregon land use program. ${ }^{120}$ OIA helped mount the successful takings challenge in the U.S. Supreme Court in Dolan v. City of Tigard, ${ }^{121}$ and led several vigorous campaigns to install property rights advocates on the Oregon Supreme Court. Most significantly for present purposes, OIA is generally credited with drafting Measure 37 and organizing the campaign leading to its adoption. ${ }^{122}$ The pro-Measure 37 campaign reportedly raised approximately $\$ 1.2$ million, which is substantially less than the $\$ 2,727,878$ raised by the no campaign, ${ }^{123}$ but nonetheless prevailed.

The basic theme of the yes campaign was "fairness," that is, that regulatory restrictions reduce the value of private property and therefore, as a matter of fairness, the public should either

state. or. us/LCD/docs/goals/goal2.pdf.

116 Or. Rev. St. $\$ \S 197.805-197.855$.

117 See David Steves, A new look at land use; An Oregon task force resumes its work after a oneyear hiatus, REGISTER-GUARD, Mar. 11, 2008; Blaine Harden, Anti-Sprawl Laws, Property Rights Collide in Oregon, WashingTON Post, Feb. 28, 2005; Timothy Egan, Oregon's Property Rights Law Kicks In, Easing Rigid Rules, N.Y. TIMES, July 25, 2006.

118 Michael C. Blumm, Enacting Libertarian Property: Oregon's Measure 37 and Its Implications, 85 DENV. U. L. REV. 279, 282 n. 8 (2007).

119 See Sullivan, Remarks to University of Oregon Symposium, 77 OR. L. REV. at 814-16.

120 David S. Hunnicutt, Oregon Land Use Regulation and Ballot Measure 37: Newton's Third Law at Work, 36 ENVTL. L. 25, 41 (2006).

121512 U.S. 374 (1994).

122 Dave Hunnicutt of Oregonians In Action-Stop 49 Campaign Spokesperson, at http://www.measure37watch.com/oregon_measure_37/2007/10/dave-hunicutt-o.html; Oregonians In Action File Measure 37 Compensation Claims for About \$5 Million, Aug. 2007, at http://www.measure37watch.com/oregon_measure_37/2007/08/oregonians-in-a.html. 123 Alan Pittman, Looming Sprawl, EUGENE WEEKLY, Jan. 25, 2007; Money in Politics Research Action Project, Top 10 Contributors to Each Side of Measures on the November 2004 Ballot, at http://oregonfollowthemoney.org/BallotMeasures/Post-Gen\%20Top\% 2010\%20Contributors.pdf. 
pay "compensation" to those affected by the restrictions or forego their enforcement. ${ }^{124}$ The public face of the campaign was Dorothy English, a 92-year-old widow who objected to restrictions affecting a parcel she had purchased with her husband in 1953. As related in numerous advertisements, their "dream was to someday divide the property, give some of it to [their] children and grandchildren, and sell the remainder for [their] retirement." ${ }^{125}$ These aspirations were supposedly dashed when Multnomah County rezoned the land as commercial forest land "even though there isn't a commercial timber operation anywhere near [the] property." ${ }^{126}$

One particular target of the yes campaign was a regulation that required owners of agricultural land to earn $\$ 80,000$ per year in revenues in two out of three years before they could build a home on the property. ${ }^{127}$ Enacted as a control on hobby farming, the regulation was attacked as a pointless restriction on agricultural operators, such as vintners, whose vines take many years to produce salable grapes, ${ }^{128}$ and an unfair burden on retirees and other small-scale operators. ${ }^{129}$ Proponents of Measure 37 publicized an anecdote involving Eugene and Barbara Prete, who bought 20 acres in Oregon in 1990, planning to use the property for a retirement home. ${ }^{130}$ When they decided to retire, they were unable to build a home on the property due to the farm-income restriction. ${ }^{131}$ More generally, the yes campaign challenged restrictions on building individual homes on agricultural and forest lands as unnecessary, unfair, and unduly burdensome. $^{132}$

124 Oregon Official 2004 General Election Online Voters' Guide, Measure 37, Arguments in Favor, available at http://www. sos. state. or. us/elections/nov22004/ guide/eas/m37_bt.html. ${ }_{125}$ Dorothy English, Measure 37, Argument in Favor, available at: http://www. sos. state. or. us/elections/nov22004/guide/meas/m37_fav.html. ${ }_{126} I d$.

127 See Laura Oppenheimer, Breaking Ground Land Owners Who Fought For Measure 37 Ready the First Cases, OREGONIAN, Nov. 22, 2004.

128 Cf. Gov. Victor Atiyeh, Gov. Barbara Roberts, \& John D. Gray, MEASure 37 RePORT AND Recommendations to Sen. Floyd J. Prozanski, Jr., Rep. Gregory H. MacPherson, Co-Chairs Joint Special CommitTeE On LAND Use FAIRNESS, 2007 Legislative SESsion 19 (Mar. 21, 2007) (recommending modification of the $\$ 80,000$ per year income rule as applied to wineries and fruit orchards).

129 See, e.g., Randal O'Toole, THE Folly OF SMART Growth, REgulation 21 (Cato Fall 2001); Eric Pryne, Voters in Oregon spoke loudly, but what were they trying to say?, SEATTLE TIMES, Apr. 11, 2005; Laura Oppenheimer, Initiative Reprises Land Battle, OREGONIAN, Sept. 20, 2004; Dave Hunnicutt, Local Opinion, REGISTER-GUARD, Oct. 14, 2007.

130 Barbara and Eugene Prete, Measure 37, Argument in Favor, available at: http://www.sos. state.or. us/elections/nov22004/guide/meas/m37_fav.html.

${ }_{131}$ Laura Oppenheimer, Initiative Reprises Land Battle, OREGONIAN, Sept. 20, 2004.

132 See Bill Moshofsky, Regulatory Taking Compensation-The Successful Oregon Measure 37 Initiative, Speech from the Ninth Annual National Conference on Private Property Rights, Property Rights Foundation of America, Inc., (2005), at http://prfamerica. org/speeches/9th/RegulatoryTakingCompensation.html; Eric Pryne, Voters in Oregon spoke loudly, but what were they trying to say?, SEATTLE TIMES, Apr. 11, 2005. 
The opposition campaign failed to develop a powerful public message or to galvanize the land use program's supporters. ${ }^{133}$ The campaign's lead message was that the measure would create "layers and layers of new government processes and procedures," and make it "more difficult for new farmers to enter the farming business. "134 This anti-government theme apparently reinforced, rather than countered, the basic message of Measure 37 advocates. The no campaign also emphasized the potential costs of the measure to taxpayers, and the likelihood that the measure would generate a great deal of litigation. ${ }^{135}$ These arguments proved inadequate to overcome the yes campaign's appeal to fairness.

The opposition campaign decided not to argue that the measure would undermine Oregon's land use protections, apparently because of a concern that voters would view the argument as implausible. The no campaign also decided against identif ying the special interests backing the measure, in particular timber companies, based on the ultimately mistaken hope that some major timber companies whose resource base is protected by the land use system would publicly oppose Measure 37. ${ }^{136}$ Thus, the no campaign arguably omitted one of its strongest potential arguments. In reality, business interests "were the driving force behind the measure" 137 and were its main beneficiaries. Timber companies, developers, and other businesses provided more than half of the funding for the yes campaign. ${ }^{138}$ The role of these special interests in the campaign was essentially ignored, leaving Dorothy English and other sympathetic individuals as Measure 37's public advocates. $^{139}$

Factors other than the strengths and weaknesses of the campaigns for and against Measure 37 also help explain its adoption. Most current Oregon residents did not participate in the political battle over the adoption of the Oregon land use program, ${ }^{140}$ and some citizens arguably took for granted the benefits of the program. Governor Ted Kulongoski was quoted as saying that he was

133 See Blumm, Enacting Libertarian Property Values, 85 DENV. U. L. REV. at 306-307.

134 Measure 37, Arguments in Opposition, available at $<$ http://www.sos. state.or.us/elections/nov22004/guide/meas/m37_opp.html>.

135 Measure 37, Arguments in Opposition, available at $<$ http://www.sos. state.or. us/elections/nov22004/guide/meas/m37_opp.html>. 136 See Blaine Harden, Oregon Rethinks Easing Land-Use Limits, WashingTON Post, Mar. 11, 2007.

137 To activist, measure 37 a bait and switch, OREGONIAN, Apr. 25, 2007; Robert Emmons, Speak out to Protect Our Land, REGISTER-GUARD, May 17, 2007.

138 Measure 37 Campaign Donors With Measure 37 Claims, at http://www.measure37watch.com/oregon_measure_37/2007/09/measure-37-do-1.html; Money in Politics Research Action Project, Donors Who Gave More than Half the Money to the Measure 37 Campaign File Over $\$ 600$ million in Claims, Could Earn Windfall on Campaign Investment, Apr. 19, 2007, at http://democracyreform. org/?q=041707release; David Sale, Measure 37 campaign donors stand to profit from claims, NEWBERG GRAPHIC, May 2, 2007.

139 See Takings Initiatives Project, Ad Wars 2004, at http://www.takingsinitiatives.org/ index.php?option=com_content $\&$ task=view \&id=87\&itemid=54.

1401.5 million Oregonians (an over $70 \%$ increase in population) moved to the state after the comprehensive land-use statute was enacted. Census, Oregon Population Growth 1960-2000. 
“not surprised [Measure 37] passed. Most Oregon voters don't understand how land-use rules affect their everyday lives, giving the pro-37 camp the upper hand in the debate." ${ }^{141}$ Media coverage of the ballot contest and the potential consequences if Measure 37 were adopted was anemic. The Oregonian, the State's leading newspaper, went so far, after the election, to publish an editorial by its public editor expressing regret that the newspaper had given only "limited coverage of the measure." ${ }^{142}$ Finally, Measure 37 may not have been a priority for voters, who apparently focused their attention on other, more controversial 2004 ballot measures addressing the use of marijuana for medical purposes and gay marriage. ${ }^{143}$

The adoption of Measure 37 unleashed a flood of claims against the state and local governments, extensive litigation, a renewed debate about the merits of Measure 37, and an intense policy discussion about how to deal with the unanticipated (or at least unpublicized) problems created by Measure 37. Eventually, the state legislature adopted a comprehensive set of amendments to Measure 37, which were approved by the state's voters on November 6, 2007. In a nutshell, these amendments rescinded Measure 37 as to existing laws, and in exchange granted those who had filed claims under Measure 37 the opportunity to build up to three additional houses (and in some instances up to ten additional houses) on protected lands. As to laws and regulations adopted in the future, Measure 49 left Measure 37 in place but significantly narrowed its scope.

Measure 37

This section provides a sketch and analysis of the key provisions of Measure 37. Because the measure was drafted by a small group of property rights advocates, and does not reflect the tug and pull of legislative politics, it was relatively succinct as well as extreme.

Measure 37 mandated that government (state agencies and/or units of local or regional government) pay "just compensation" when it enacts or enforces a regulatory restriction that "reduce[s] the fair market value of [real] property, or any interest therein." 144 The measure identified no threshold level of impact for making a claim. However, the measure allowed government entities to avoid liability by "modify[ing]," remov[ing], or not apply[ing]" the

141 See Laura Oppenheimer, Land-Use Laws on Turf that is Uncharted, OREGONIAN, Nov. 4, 2004. 142 Michael Arrietta-Walden, the Public Editor, Measure 37 Coverage Was Too Limited, Late, OREGONIAN, Nov. 14, 2004.

143 National Conference of State Legislatures, Voters Decide High-Profile Issues on State Ballots, Nov. 9, 2004, at http://www.ncsl.org/programs/legismgt/ statevote/ir2004.htm.

144 Ballot Measure 37, available at http://www. sos. state.or. us/elections/nov22004/ guide/meas/m37_text.html. 
challenged regulation within a limited period after the filing of a claim. ${ }^{145}$ The popular shorthand description of Measure 37 was that it imposed a "pay or waive" mandate.

Measure 37 was expansively retroactive. Claimants eligible to challenge pre-existing regulations included owners who purchased property before the offending regulation was adopted, as well as owners who obtained property from a family member who acquired the property prior to the regulation's adoption. In practice, this meant that thousands of land owners were entitled to file claims based on Oregon's comprehensive land use laws of the 1970s.

If the government elected to pay, the "just compensation" was required to "be equal to the reduction in the fair market value of the affected property interest resulting from enactment or enforcement of the land use regulation as of the date the owner ma[de] written demand for compensation." 146 While Measure 37 resulted in virtually no payments, the issue of how to calculate compensation under the measure was a matter of heated debate. ${ }^{147}$ Compensation could be paid from funds "specifically allocated" for that purpose, or from other "available funds." 148

If the government was unable or unwilling to pay, "the governing body responsible for enacting the land use regulation" was authorized to "modify, remove, or not to apply the land use regulation ... to allow the owner to use the property for a use permitted at the time the owner acquired the property. "149 On its face, this waiver authority could only affect regulations adopted while the current owner held the property, in contrast to a payment of compensation, which could reach regulations adopted during an ancestor's tenure.

The measure included five exemptions from the pay or waive mandate, including regulations that (1) restricted "activities commonly and historically recognized as public nuisances under common law;" (2) regulated "activities for the protection of public health and safety, such as fire and building codes, health and sanitation regulations, solid or hazardous waste regulations, and pollution control regulations;" (3) were necessary "to comply with federal law;" (4) restricted "the use of a property for the purpose of selling pornography or performing nude dancing;" or (as discussed above) (5) were enacted before the claimant, or a family member, acquired the property. $^{150}$

145 Id. Measure 37 mandated that government either pay compensation or waive the regulations within 180 days from the date the property owner filed his written demand; if the government was unable or unwilling to address the claim within 180 days, the owner was free to file a lawsuit seeking compensation.

146 Id.

147 See, e.g., Edward J. Sullivan, Through a Glass Darkly: Measuring Loss Under Oregon's Measure 37, 39 URB. LAW 563, 576-602 (2007) (surveying the alternative theories).

148 Ballot Measure 37, available at http://www. sos. state.or. us/elections/nov22004/ guide/meas/m37_text.html.

149 Id.

150 Id. 
To initiate a claim, a land owner was required to submit a "written demand" to the responsible government entity or entities, but there was no prescribed set of data or supporting documentation that had to be filed with the claim. ${ }^{151}$ The measure permitted state or local governments to adopt "procedures for the processing of claims," but compliance with the procedures was not made a prerequisite for filing a claim and a claim could not be rejected for failure to follow the procedures. ${ }^{152}$ In addition, the measure stated that "A decision by a governing body under this act shall not be considered a land use decision as defined in ORS 197.015(10)," ${ }^{153}$ making clear that government actions under Measure 37 were not subject to administrative review before the Land Use Board of Appeals. ${ }^{154}$ The measure included a soft two-year deadline for the filing of facial claims based on regulations in place on the date of adoption of Measure 37, after which claims based on such regulations could only be brought on an as applied basis. ${ }^{155}$

The Consequences of Measure 37

Our basic conclusion is that Measure 37, if it had remained in place, would have essentially destroyed the Oregon land use program and, over time, encouraged a sprawling development pattern similar to that afflicting many other states. While the measure imposed a chill on new regulatory initiatives, as in Florida, the far more important consequence was the threatened unraveling of decades-old regulations limiting development outside of designated urban growth boundaries and protecting productive agricultural and forest lands.

Claims Data. As of November 2007, when Measure 49 was enacted and the filing of new claims under Measure 37 ceased, property owners had filed 7,717 claims affecting approximately 800,000 acres and demanding compensation totaling approximately $\$ 20$ billion. $^{156}$

The large volume of claims filed under Oregon Measure 37 stands in dramatic contrast to the much smaller number of claims filed in Florida (and other states with takings legislation). The primary reason for the relatively large number of claims in Oregon was the retroactive nature of Measure 37, which created a large universe of land owners immediately eligible to file claims. In addition, Measure 37 imposed no filing requirements other than the claims be in writing; claimants were not even required to submit an appraisal with their claims. Thus, a simple one-page

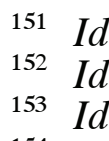

154 Rebekah R. Cook, Incomprehensible, Uncompensable, Unconstitutional: The Fatal Flaws Of Measure 37, 20 J. ENVTL. L. \& LiTIG. 245, 256 (2005).

155 Ballot Measure 37, available at http://www. sos. state. or. us/elections/nov22004/ guide/meas/m37_text.html.

156 Portland State University, Measure 37: Database Development and Analysis Project, available at http://www.pdx.edu/ims/m37database.html\#regioncounty (database including claims against the state, regional, and local governments); see also Oregon Department of Land Conservation and Development, Measure 37 Summaries of Claims, at http://www.lcd.state.or.us/LCD/MEASURE37/summaries_of_claims.shtml (database including only state claims). 
document demanding millions of dollars commonly sufficed to initiate the Measure 37 process. Finally, as hundreds and then thousands of land owners filed claims, many of which were reported in the local media, other eligible claimants apparently decided to join "the crowd," swelling the total number of claims.

The majority of claims filed under Measure 37 involved residential development, ${ }^{157}$ but only a fraction of these claims were proposals to build single-family homes that were the focus of the public campaign on behalf of Measure 37. One authoritative analysis of Measure 37 claims prepared for the Oregon legislature, which addressed claims involving residential projects, estimated that $40 \%$ of the residential claims involved proposals to build between one to three homes, $31 \%$ of the claims involved proposals to build four to nine residences, and $28 \%$ of the claims involved subdivisions of over ten lots. ${ }^{158}$ The claims involving larger subdivisions were disproportionately important in terms of area, covering $71 \%$ of the total acreage affected by Measure 37 residential claims. ${ }^{159}$ Thus, focusing on the residential claims alone, the primary beneficiaries were land developers rather than individuals seeking a home for themselves and their families.

500,000 acres of farmland were targeted with claims involving residential subdivisions and other development. ${ }^{160}$ The majority of the Measure 37 claims were filed in the Willamette Valley, Oregon's richest agricultural area, ${ }^{161}$ and the majority of these were on land zoned for agricultural use. $^{162}$ In Washington County, located in the Willamette Valley, Measure 37 claims were filed on $20 \%$ of the county's 121,719 acres of farmland. ${ }^{163}$

157 According to the Portland State University database of Measure 37 claims, out of the 7,717 claims that were filed, approximately $57 \%$ of claimants sought to build homes, approximately $1 \%$ sought some other use, and the remaining $41 \%$ involved claims where the claimant did not specify a proposed use or no use was proposed. Portland State University, Measure 37: Database Development and Analysis Project, available at http://www.pdx.edu/ims/m37database. html\#regioncounty.

158 Atiyeh, et al., MEASURE 37 REPORT AND RECOMMENDATIONS TO SEN. Floyd J. PROZANSKI, JR., REP. GREGORY H. MACPHERSON, CO-CHAIRS at 12. For another analysis of Measure 37 claims, see Henry R. Richmond \& Timothy G. Houchen, MEASure 37, Is IT DOING What OREGON Voters WANTED? 1, 3-6, 7-10 (American Land Institute Sept. 17, 2007).

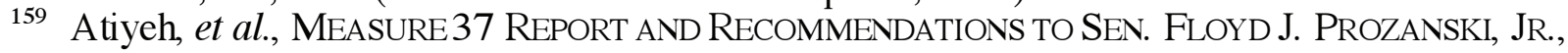
REP. GREGORY H. MACPHERSON, CO-CHAIRS at 12.

160 Brian Hines, Restore fairness of property rights, STATESMAN JOURNAL, Nov. 4, 2007; Richmond \& Houchen, MEASURE 37 at 1, 7-10.

161 Richmond \& Houchen, MEASURE 37 at 11-13; Brian Hines, Restore fairness of property rights, STATESMAN JOURNAL, Nov. 4, 2007.

162 Jim Johnson, Presentation, Willamette Valley Measure 37 Claims, Oregon Department of Agriculture, at http://www.oregon. gov/ODA/NRD/docs/ pdf/m37/ m37_ppt.pdf.

163 Richmond \& Houchen, MEASURE 37 at 11-13. 
Many of the most controversial claims involved non-residential development, including billboards, ${ }^{164}$ casinos, ${ }^{165}$ tourist centers and recreational vehicle parks, ${ }^{166}$ strip-malls and shopping centers, ${ }^{167}$ industrial parks, ${ }^{168}$ hotels, ${ }^{169}$ golf courses, ${ }^{170}$ marinas, ${ }^{171}$ mines,${ }^{172}$ and power plants. ${ }^{173}$ Measure 37 claims seeking compensation or waivers for billboards (including one proposal to erect 54 billboards in Portland alone ${ }^{174}$ ) were especially controversial given Oregon's longstanding ban on billboards. ${ }^{175}$ Another notorious Measure 37 claimant proposed to construct a one million square-foot mega-mall in the middle of protected farm land. ${ }^{176}$

Many of the largest Measure 37 claims, both in terms of acres involved and the amount of compensation demanded, were filed by timber companies. For example, Plum Creek filed a claim seeking waivers of regulations that would have allowed it to pursue residential development of 32,000 acres located along the Pacific Coast in Lincoln and Coos counties, or, in the alternative, demanding \$94.8 million in compensation. ${ }^{177}$ Stimson Lumber Company filed claims seeking

164 See, e.g., Marcus Hathcock, Measure 37 bringing twin billboards to Boring, SANDY Post, Mar. 7, 2007; Associated Press, Billboard companies use Measure 37 against limits, CORVALLIS GAZETTE-TIMES, Feb. 9, 2006; Luciana Lopez, Land-use decision will allow billboards, OREGONIAN, Aug. 19, 2005.

165 See, e.g., Ron Soble, Farmland owners claim right to build casinos, OREGONIAN, Jan. 26, 2005.

166 See, e.g., Damian Mann, County OKs Measure 37 claim for a tourist center, MAIL TRIIBUNE, Sept. 1, 2005.

${ }_{167}$ See, e.g., In case you missed it. . ., REGISTER GUARD, Jan. 10, 2008; Pending Measure 37 Claims, Metro, at http://www.metro-region. org/index.cfm/go/by.web/id=19165.

168 See, e.g., Randi Bjornstad, Campaign Donors file big claims under law, REGISTER-GUARD, Sept. 3, 2006.

${ }_{169}$ See, e.g., Jeff Wright, Claims spur watershed warning, REGISTER GUARD, Feb. 8, 2007.

170 See, e.g., Randi Bjornstad, Potential developers prowl for Measure 37 windfalls, REGISTER

GuARD, Dec. 6, 2006; Ken O'Toole, County feels Measure 37 claims crush, TILLAMOOK

HEADLIGHT HERALD, Dec. 12, 2006.

171 See, e.g., id.

172 See, e.g., Sightline Institute, TwoYears of MEAsure 37: OREgON's ProperTy Wrongs 5-7 (Feb. 2007); Timothy Egan, Oregon's Property Rights Law Kicks In, Easing Rigid Rules, N.Y. TIMES, July 25, 2006.

173 See, e.g., Sightline Institute, TwoYEARS OF MEASURE 37 at 5-7.

174 See, e.g., Here Come the Billboards, REGISTER-GuARD, Aug. 19, 2007; Floyd Prozansk, Law of the Land, REGISTER-GUARD, Oct. 14, 2007.

175 See, e.g., Marcus Hathcock, Measure 37 bringing twin billboards to Boring, SANDY Post, Mar. 7, 2007; Associated Press, Billboard companies use Measure 37 against limits, CORVALLIS GAZETTE-TimES, Feb. 9, 2006.

176 Friends of Polk County, Oregon, Measure 37 Mega-Mall Approved on Polk County Farmland, HOMESTEAD (Spring 2005), available at http://www.fopc-oregon.org/ Assets/newsletters/2005/2005_spring.pdf.

177 Sightline Institute, Two YeARS OF MEASure 37 at 16; Alan Pittman, Looming Sprawl, EugENE WEEKLY, Jan. 25, 2007; Eric Mortenson, Timber firm pulls land-use claims, OREGONIAN, Aug. 10, 2007. Plum Creek later withdrew its claims. Id. 
compensation of approximately $\$ 269$ million on over 47,384 acres of land ${ }^{178}$ and SDS Lumber Company filed claims seeking over $\$ 120$ million on 1,465 acres of forestland in Hood River. ${ }^{179}$

Implementation of Measure 37. On its face, Measure 37 raised numerous questions about how it should be interpreted and applied. Some of the most important questions included who was eligible to file claims for compensation, how compensation was supposed to be calculated, what governmental entity was responsible for paying compensation, what governmental entity had authority to waive a regulatory restriction, whether land owners could transfer their rights under Measure 37 to purchasers of their land, whether land owners with valid Measure rights still had to comply with building codes and other health and safety regulations, and the scope of the various exemptions to the pay or waive mandate. ${ }^{180}$ Several of these issues were the subject of ongoing litigation when Measure 49 was adopted. ${ }^{181}$

All told, Measure 37 claimants filed at least 300 lawsuits against the state and local governments. ${ }^{182}$ Neighbors also filed lawsuits challenging the issuance of waivers by the state or local governments. ${ }^{183}$ In several instances cities sued counties over their approval of Measure 37 claims. ${ }^{184}$ The volume of controversy was even greater at the administrative level; neighboring land owners wrote over 85,000 letters to the state registering objections or other comments on over two thirds of the claims filed with the state. ${ }^{185}$

A handful of local governments, including Eugene, Portland, and Wilsonville, responded to Measure 37 by passing ordinances authorizing neighbors whose land was affected by a claim

178 Richmond \& Houchen, MEASURE 37 at 18; Money in Politics Research Action Project, Donors Who Gave More than Half the Money to the Measure 37 Campaign File Over $\$ 600$ million in Claims, Could Earn Windfall on Campaign Investment, Apr. 19, 2007, available at http://democracyreform. org/?q=041707release.

${ }_{179} I d$.

180 See, e.g., Jeannie Lee, Tying Up Loose Ends: Resolving Ambiguity in Ballot Measure 37's Public Health and Safety Exemption, 38 EnvTL. L. 209 (2008); Sullivan, Through a Glass Darkly, 39 URB. LAW. at 566-76; Blumm, Enacting Libertarian Property Values, 85 DENV. U. L. REV. at 306-307; Rebecca L. Puskas, Note, Measure 37's Federal Law Exception: A Critical Protection for Oregon's Federally Approved Land Use Laws, 48 B.C. L. REV. 1301 (2007); Hannah Jacobs, Searching For Balance in the Aftermath of the 2006 Takings Initiatives, 116 YALEL.J. 1518 (2007); Edward J. Sullivan, Year Zero: The Aftermath of Measure 37, 38 URB. LAW. 237 (2006). 181 See, e.g., Eric Mortenson, Legal tangles cloud Oregon land-use law, OREGONIAN, Feb. 6, 2008 (discussing litigation that was pending when Measure 49 was approved).

${ }_{182}$ Oregon Department of Justice, Pending Measure 37 Litigation, Oct. 17, 2007, at http://www.doj. state.or.us/hot_topics/measure37litigation. shtml.

${ }_{183}$ Oregon Department of Land and Conservation, Measure 37 Summaries of Claims, Dec. 5, 2007, at http://www.oregon.gov/LCD/MEASURE37/summaries_of_claims. shtml\#Summaries_of_Claims_Filed_in_the_State.

184 See, e.g., Damian Mann, Measure 37: one year later, MAIL TriBUnE, Dec. 5, 2005; Davis Bates, Newberg sues county over Measure 37, NEWs REGISTER, Dec. 6, 2005.

185 See Oregon Department of Land and Conservation, Measure 37 Summaries of Claims, Dec. 5, 2007, at http://www.oregon.gov/LCD/MEASURE37/summaries_of _claims.shtml\#Summaries_of_Claims_Filed_in_the_State. 
approved under Measure 37 to sue the owner of the subject property. ${ }^{186}$ While apparently no successful suits were filed under these ordinances, they provide a taste of the conflict engendered by Measure 37. Not surprisingly, some critics began to call Measure 37 the "Hate Your Neighbor Act. $" 187$

Notwithstanding the numerous questions and controversies raised by Measure 37, it was apparent from the first that Measure 37 created a powerful new legal tool for land owners who objected to regulatory restrictions. So long as it was clear that the offending regulation was adopted after the claimant or an ancestor purchased the property, the owner generally was entitled either to some level of compensation or to waiver of the regulation. In a handful of instances, state and local governments refused to waive restrictions on the development of steep slopes and floodplain regulations, invoking the exemption for regulations designed to protect "public health and safety." 188 In addition, a Circuit Court judge ruled that land use regulations in the Columbia River Gorge National Scenic Area were protected from Measure 37 claims by the exemption for regulations "necessary to comply with federal law." 189 Apart from these exceptional cases, however, filing a successful Measure 37 claim was generally equivalent to the proverbial shooting of fish in a barrel.

Endless Waivers. Measure 37 appeared, on the surface, to offer the possibility of keeping existing regulations in place while paying compensation to those affected by the regulations. Indeed, immediately after the adoption of Measure 37, Governor Ted Kulongoski publicly insisted that regulations would not be waived and that some mechanism would be found to pay the

186 See, e.g., Alan Pittmann, Unraveling Measure 37; Details could tie sprawl-threatening measure up in knots, EUGENE WEEKLY, Dec. 2, 2004; Glenn Klein, MEASURE37: SOME PRELIMINARY THOUGHTS FOR IMPLEMENTATION BY CITIES (Nov. 2004), at http://www.ci. wilsonville. or. us/Index.aspx?page=385; WILSONVILLE ORD. 575, available at http://www.ci.wilsonville. or. us/Index.aspx?page=385; PORTLAND ORD. Ch. 5.75 Sec. 5.75.080, Apr. 2005, available at http://www.portlandonline.com/index.cfm?c=39960.

${ }_{18}$ Blaine Harden, Oregon Rethinks Easing Land-Use Limits, WASHINGTON POST, Mar. 11, 2007. 188 See, e.g., Oregon Department of Land Conservation \& Development, Ballot Measure 37 Claim for Compensation: Final Staff Report and Recommendation, Claim No. M119116 (June 23, 2005), available at http://www.oregon.gov/LCD/docs/measure37/

finalreports/M119116_CCobos_Final_Report.pdf (granting the claim but exempting health regulations, stating "To the extent that state land use laws, specifically Statewide Planning Goal 7, require restrictions on development of steep slopes in order to protect public health and safety, these regulations are exempt from a claim under Measure 37, Section 3, and shall remain in effect."); Oregon Department of Land Conservation \& Development, Ballot Measure 37 Claim for Compensation: Final Staff Report and Recommendation, Claim No. M118919 (June 3, 2005), available at http://www.oregon. gov/LCD/docs/measure37/finalreports/M118919_Fergusson_Final_Report.pdf (concluding that to the extent floodplain restrictions implemented Statewide Planning Goal 7 addressing natural hazards, "such restrictions are exempt under Ballot Measure $37 "$ ").

189 See Columbia River Gorge Commission v. Stephen Struck, No. 050051CC (Hood River County Cir. Ct. Feb. 7, 2007). 


\section{Louisiana and Mississippi}

In 1995, at the height of the property rights movement in the United States, Louisiana and Mississippi adopted takings measures narrowly designed to provide a compensation remedy for owners of agricultural and forest lands subject to regulatory restrictions. Neither piece of legislation appears to have had any impact.

The Louisiana property rights legislation grants owners of agricultural or forest lands a right of action against state agencies or local governments based on government actions "that cause[] a diminution in value of a parcel of private agricultural [or forest] property." "diminution in value" as "an existent reduction of twenty percent or more of the fair market value or the economically viable use of, as determined by a qualified appraisal expert, the affected portion of any parcel of private agricultural property or the property rights thereto for agricultural purposes, as a consequence of any regulation, rule, policy, or guideline promulgated for or by any governmental entity." $\mathrm{b}$ When regulations diminish the value of agricultural or forest lands according to the definition set forth in the Act, the owner is entitled to compensation. ${ }^{c}$ The government may "rescind or repeal" the rule, but the government would remain liable for "damages sustained by the property owner to his affected property which were caused by the application of the rescinded or repealed rule or regulation," including attorneys fees and costs. ${ }^{\mathrm{d}}$ The legislation includes several broad exemptions, including for state statutory requirements and actions taken to comply with federal laws or regulations. ${ }^{\mathrm{e}}$ Like the Texas property rights legislation, the Louisiana legislation requires the government to "prepare a written assessment of any proposed governmental action prior to taking any proposed action that will likely result in a diminution in value of ... property. " However, the legislation creates no right of action making this requirement enforceable in court. No lawsuits seeking compensation for the diminution in value of property have apparently been filed under the Act, perhaps because there has been no push in Louisiana for state or local legislation that would significantly restrict the uses of agricultural lands.

The Mississippi Agricultural and Forestry Act also creates a takings remedy narrowly focused on restrictions on the use of land for forestry or agricultural activities. The Act provides a right of action for a government measure that "prohibits or severely limits the right of an owner to conduct forestry or agricultural activities." value the fair market value of forest or agricultural land (or any part or parcel thereof) . . . by more than forty percent (40\%) of their value before the action." $h$ The government is authorized to "repeal" or rescind the offending regulation, and if it does so before a final judicial decision, the claimant is entitled to "to recover its damages arising out of the action before the repeal," as well as its attorneys fees and certain costs, at the discretion of the court. ${ }^{i}$ On the other hand, an attempted repeal after a final judicial decision "shall not entitle the state to refuse payment, obtain a return of payment (if made) or result in ownership in the property by the state (absent a taking of one hundred percent (100\%) of the property)." ${ }^{\mathrm{j}}$ The Act includes a relatively lengthy list of exemptions, including for regulations designed to "prohibit activities that are noxious in fact or are harmful to the public health and safety," fish and game laws, and orders that are "issued as a result of a violation of state law. ${ }^{k}$ Again, there are no reports of actual litigation under this legislation, in part because of its very narrow scope, and probably in part for the same reasons there has been no litigation involving the Louisiana legislation.

${ }^{b}$ LA. REv. St. § 3:3610; LA. REv. ST. § 3:3602(11); LA. REV. ST. § 3:3623(C).

${ }^{c}$ LA. REV. ST. § 3:3602(11).

${ }^{d}$ LA. REv. ST. $\$$ 3:3610(D), (F); LA. REV. ST. §§ 3:3623(C)-(E); LA. REV. ST. § 3:3602(11).

e LA. REV. ST. § 3:3610(F); LA. REV. ST. § \$ 3:3623(D)-(E).

${ }^{f}$ LA. REV. ST. § 3:3602(12); LA. REV. ST. § 3:3622(3).

g LA. REV. ST. § 3:3609; LA. REV. ST. § 3622.1.

h Miss. CODE § 49-33-7(e); Miss. CODE § 49-33-9(1).

Miss. CODE $§$ 49-33-7(h).

i Miss. CODE $\$$ \$49-33-9(2)-(3).

j Miss. CODE $\S 49-33-9(2)$.

k MisS. CODE $§ 49-33-7(\mathrm{e})$. 
claims. ${ }^{190}$ In practice, however, in all but one of the cases in which land owners filed valid Measure 37 claims, the government responded by waiving the regulations. There is apparently no authoritative record of the exact number of Measure 37 waivers issued, but they were undoubtedly in the thousands. ${ }^{191}$

What accounts for this remarkably uniform response to Measure 37, which apparently no one in the debate over Measure 37 predicted? The basic explanation is that the state and local governments lacked the funds to pay the claims. ${ }^{192}$ Measure 37 provided no dedicated funding to pay claims. Moreover, valid Measure 37 claims, like constitutional regulatory takings judgments, were generally understood to be uninsured and uninsurable. As a result, government officials would have been forced to spend extremely limited general funds from agency or local government budgets, or seek special legislative appropriations, to cover claims. For financially strapped Oregon governments, waivers were not merely the path of least resistance, but a practical necessity.

The daunting fiscal challenge of paying Measure 37 claims was compounded by the large volume of claims. Even assuming it were possible for a local government to pay one or a few claims, it could not pay the dozens of similar claims that could potentially be filed. From the local government perspective, a decision to pay a single claim likely would have generated many more claims for compensation. In addition, paying in one or a few cases would have raised the daunting policy and political challenge of deciding who deserved payment and who deserved a waiver. A uniform policy of waivers avoided opening this Pandora's Box.

Finally, the waiver option was appealing to local governments because it avoided the technical complexities of attempting to calculate appropriate compensation. There was substantial debate about whether a compensation award should be calculated using the traditional method in constitutional takings cases, based on the value of the land "with" and "without" the regulation, or using some other method. ${ }^{193}$ In addition, Measure 37 did not require a claimant to provide an appraisal with the claim, placing the burden of preparing the appraisal on the government. Furthermore, government officials had only 180 days to conduct their analysis and decide whether

190 Jeff Barnard, Two land owners file Measure 37 claims on first day, ASSOCIATED PRESS, Dec. 2 , 2004; Felicity Barringer, Property Rights Law May Alter Oregon Landscape, N.Y. TIMES, Nov. 26, 2004.

191 The state reported that as of December 5, 2007, it had closed 3,418 claims, and issued 3,237 final orders. Oregon Department of Land and Conservation, Measure 37 Summaries of Claims, Dec. 5, 2007, at http://www.lcd. state.or.us/LCD/MEASURE37/

summaries_of_claims.shtml. A random survey of the final orders published on the state's website indicates that the state dealt with a large majority of the claims by waiving the regulations. For links to the final orders issued on Measure 37 claims, see Oregon Department of Land and Conservation, Measure 49 Website, at http://www.lcd. state. or. us/LCD/MEASURE49/index. shtml.

192 Atiyeh, et al., MEASURE37 REPORT AND RECOMMENDATIONS TO SEN. FloYd J. PROZANSKI, JR., REP. GREGORY H. MACPHERSON, CO-CHAIRS at 2.

193 See, e.g., Sullivan, Through a Glass Darkly, 39 URB. LAW. at 576-602; W.K. Jaeger \& A.J. Plantinga, THE ECONOMICs BeHIND MEASURE 37 (Oregon State University Feb. 2007). 
to pay compensation or waive the regulation. ${ }^{194}$ Because of all these factors, state and local governments had ample encouragement to avoid paying and simply issue a waiver instead.

The lone case in which a local government paid compensation rather than waive the regulation helps to illustrate why compensation was so rare. In October 2006, the Commissioners of Prineville, Oregon, voted to pay Grover and Edith Palin \$48,000 in response to their Measure 37 claim demanding either compensation or a waiver permitting them to build a home on two acres of their property. Jerry Gillham, the assistant city manager, said of the offer "We don't want to see rooflines on our rim rock." 195 The Palins had purchased 15.7 acres on the edge of the rim rock overlooking the City and the Crooked River Valley in 1963. ${ }^{196}$ While the City's offer essentially matched the Palins' compensation demand, they rejected the offer and filed a new Measure 37 claim encompassing their entire ownership and seeking $\$ 1.5$ million in compensation or permission to build a diner and a hotel or condominiums on the property. ${ }^{197}$ Mr. Palin was quoted as stating, “Edith and I wanted a retirement home; we didn't get it, so now if we don't get that we might as well see how much money we can get. . . I'm looking at pretty close to $\$ 5$ million." 198 The Palins' strategy of upping the ante was partly successful, because the City ultimately paid the Palins $\$ 180,000$ to prevent the proposed development. ${ }^{199}$ City council members who approved the payment believed they were "bowing to public sentiment when they declined permission for the Palins to build their home." 200

Several unusual factors made the City willing to pay to resolve this claim. The proposed development on the rim rock edge seriously threatened the scenic beauty of the community and generated vocal public opposition. In addition, most of the land on the rim rock was already publicly owned, meaning that paying the Palins did not expose the City to the risk of numerous similar claims. The one-of-a-kind nature of this claim distinguished it from the thousands of other Measure 37 claims.

194 Local governments received a limited respite when the state enacted H.B. 3546, which extended from 180 days to 540 days the period for government entities to review and act upon claims submitted pursuant to Measure 37 after November 1, 2006. Press Release, Governor Signs into Law One-Year Extension for Review of Measure 37 Claims (May 10, 2007). The state adopted this legislation in response to the filing of approximately 3,500 claims immediately prior to the December 4, 2006 deadline for filing facial Measure 37 claims. Id.

195 Matthew Preusch, Prineville offers Measure 37 pay, OREGONIAN, Oct. 26, 2006.

196 City of Prineville Minutes 6-14 (May 8, 2007), available at http://www.cityof prineville.com/assets/doc/ccmlibrary/MINUTE\%205-08-07.pdf. ${ }_{197}$ Measure 37 claims patchwork turns into checkmate, OREGONIAN, Dec. 10, 2007. 198 Ore. couple will refile Measure 37 claim after landmark decision, ASSOCIATED PRESS, Nov. 30, 2006.

199 Prineville makes Oregon's first Measure 37 payment, AssocIATED PRESS, Sept. 14, 2007.

200 Associated Press, First couple to get Measure 37 money seek to refile claim, REGISTER GUARD, Dec. 1, 2006. 
Granting a Measure 37 waiver was not the equivalent of issuing a building permit, and various obstacles still confronted owners who sought to proceed with development on the basis of a waiver. A Measure 37 waiver only applied to the specific regulation that was the subject of the claim. In some cases other, pre-existing regulations restricted or at least placed conditions on development of the property. ${ }^{201}$ Rules and regulations concerning water supply and sanitation, regardless of when they were adopted, were generally viewed as exempt from Measure 37 based on the "health and safety" exemption. ${ }^{202}$ In addition, some development projects required access to inf rastructure, and Measure 37 imposed no affirmative obligation on governments to make public facilities and services available to claimants. ${ }^{203}$ For all of these reasons, apparently only a few hundred claims, at most, were converted into actual developments or vested development rights by the time Measure 37 was superseded by Measure 49. There is no central database of vested claims, however, and therefore the full extent of the development authorized under Measure 37 will only become clear as individual owners seek to establish legal entitlements to develop their properties. ${ }^{204}$

While the primary consequence of Measure 37 was a roll back of pre-existing regulatory standards, Measure 37 also had a chilling effect on any significant new regulatory initiatives. ${ }^{205}$ In general, the chilling effect was less pronounced, or at least less visible, than in Florida, probably because Oregon had a more fully developed land use regulatory regime. Nonetheless, it is apparent

201 See, e.g., Umatilla County Board of Commissioners, Meeting Minutes, Hearing on Measure 37 Claim, \#M37-043-06: Bert L. \& Barbara A. McCormack (May 3, 2007), available at http://www.co. umatilla.or.us/deptwebs/planning/bcc minutes/07may03. brd.m37.htm (ruling that owners were entitled to waiver of 160 -acre minimum lot size requirement but were still subject to pre-existing 80-acre minimum lot size requirement).

202 See Peter Zuckerman, Canby man sues state, county, OREGONIAN, Dec. 6, 2007 (quoting Mike Judd, Clackamas County's land-use attorney, as saying "You don't waive regulations dealing with health and safety. ... Y You have to have paved streets and sewers. You have to avoid geological hazards.").

203 See, e.g., David Bates \& Nicole Montesano, Big claim raises big issues, NEW-REgISTER, Sept. 10, 2005.

204 Pursuant to Measure 49, in January 2008 the state began mailing notices to Measure 37 claimants on how to proceed to establish the existence of vested rights, and claimants had 90 days to elect how to proceed. H.B. $3540 \S 8$; Oregon Department of Land Conservation and Development, Measure 49 Guide, available at http://www.oregon.gov/LCD/MEASURE49/docs/general/m49_guide.pdf. The state finished mailing out notices in March 2008. Oregon Department of Land Conservation and Development, Press Release, State completes Measure 49 notice mail-out, Mar. 31, 2008, available at http://www.oregon.gov/LCD/news_2008.shtml\#State_completes_Measure _49_notice_mail_out. Local governments have also adopted procedures for determining whether claimants acquired vested rights to complete and continue the use described in a waiver. See, $e, g,$. Marion COUNTY ORD. 1255, available at http://www.co.marion. or. us/NR/rdonlyres/E569FC78-A037-4F35-B58C637ADAA504C2/9943/M49Ord.pdf. 205 See Alan Pittmann, Unraveling Measure 37: Details could tie sprawl-threatening measures in knots, EUGENE WEEKLY, Dec. 2, 2004 ("Already local government attorneys are advising clients to hold back on needed new regulations to protect livability and control sprawl for fear of Measure 37 claims."). 
that Measure 37 played a role in derailing plans to enact more stringent regulations addressing stream corridor preservation ${ }^{206}$ and historic district protection. ${ }^{207}$

Public Disenchantment with Measure 37. Virtually from the day Measure 37 was adopted public support for the measure began to erode. Many voters apparently believed that Measure 37 would operate "as a common-sense tool that Ma and Pa could use to cut through red tape" and "allow property owners to build homes for their children and grandchildren on their rural land. "208 As hundreds and then thousands of claims were filled, involving major subdivisions in rural areas as well as mines, billboards, and large commercial developments, public sentiment about the measure began to change. In March 2007, Governor Kulongoski said, "As every day goes by, more and more people are saying, 'This isn't what we thought we were voting for.' " 209

Part of this shift in public attitudes about Measure 37 is attributable to the intensive media focus on the controversies generated by the measure. Whereas only about 200 newspaper articles published before the election even mentioned the measure and less than 80 discussed it in any detail, almost 3000 newspaper articles about Measure 37 were published between 2004 and 2008. While the Oregonian gave limited attention to Measure 37 in the run up to the 2004 election, the newspaper assigned a reporter to cover the implementation of the measure on a full-time basis. ${ }^{210}$

Another explanation for the change in public attitude is that Oregonians had never swayed in their support for the land use program. As discussed, in spite of voting for Measure 37, the voters had previously rejected several ballot proposals that would have rolled back the land use program. Moreover, opinion polls taken around the time of the passage of Measure 37 indicated that Oregonians still supported the land use system. ${ }^{211}$ While the voters' approval of Measure 37 apparently signaled a desire to address fairness issues, public attitudes about the measure shifted as

206 See Laura Oppenheimer, Metro ready to adopt land rules, OREGONIAN, Sept. 1, 2005 (describing how Metro abandoned a regulatory approach to stream corridor protection in the aftermath of Measure 37).

207 See Susan Palmer, Historic district proposal pits neighbor vs. neighbor, REGISTER-GUARD, Jan. 2, 2006 (describing role of property rights concerns in derailing proposed historic district designation for South University Neighborhood in Eugene).

${ }_{208}$ Blaine Harden, Oregon Rethinks Easing Land-Use Limits, WASHINGTON PosT, Mar. 11, 2007.

209 Id.

210 Michael Arrietta-Walden, The Public Editor Measure 37 Coverage was too Limited, Late, OREGONIAN, Nov. 14, 2004.

${ }^{211}$ See Timothy Egan, Oregon's Property Rights Law Kicks In, Easing Rigid Rules, N.Y. TIMES, July 25, 2006. Similarly, after the vote on Measure 7 in 2000, follow-up focus group interviews indicated that "many who voted in favor of this measure felt that they were speaking to the issue of fairness and not against the planning system." Deborah Howe, What's On the Horizon for Oregon Planners? Longer View; Evaluation of Land Use Planning System, JOURNAL OF THE AmERICAN PlanNing Association, Sept. 22, 2004. 
voters came to see support for Measure 37 as inconsistent with their support for the land use program. $^{212}$

An October 2006 poll taken by the national polling firm of Greenberg Quinlin Rosner Research revealed that voters, if given the opportunity to cast their votes again, would oppose Measure 37 by 2 -to-1, with $48 \%$ voting no, and only $29 \%$ voting yes. ${ }^{213}$ The poll also reported that $86 \%$ of voters had heard of Measure 37 and $56 \%$ of voters said they had heard a lot, ${ }^{214}$ indicating that voters were paying attention to Measure 37's impacts. While a plurality (48\%) of all voters believed that Measure 37 was a mistake, a significant majority (62\%) of voters who had heard a lot about Measure 37 reached the same conclusion. ${ }^{215}$ In other words, the more citizens knew about Measure 37, the more they disliked it.

A poll taken in early 2007 by the firm of Fairbanks, Maslin, Mausllin \& Associates showed that $69 \%$ of Oregon voters thought the measure should be either repealed or amended as soon as possible. $^{216}$ While the poll revealed public sympathy for the desire of land owners to build one or a few homes on their land, it also revealed strong opposition to commercial development or subdivision of farm and forest lands. Another poll around the same period sponsored by 1000 Friends of Oregon showed $61 \%$ of Oregon voters in favor of either repealing or amending Measure $37 .^{217}$

\section{Measure 49}

Political leaders in Oregon responded to this groundswell in favor of curbing Measure 37. In June 2007, at the urging of Governor Kulongoski, and after prolonged negotiations, the legislature passed House Bill 3540, a comprehensive set of amendments to Measure 37, and referred the legislation to the voters for their approval or disapproval. ${ }^{218}$ The legislation was

212 See Peter Zuckerman, Measure 37 Maps Elicit Shock among Residents, OREGONIAN, May 17, 2007; Atiyeh, et al., MEASURE37 RePORT ANd ReCOMMENDATIONS to SEN. Floyd J. ProzANSKI, JR., REP. GREGORY H. MACPHERSON, CO-CHAIRS at 9-13, 19-20.

${ }^{213}$ Greenberg Quinlin Rosner Research, Voters Have Buyer's Remorse for Measure 37 in Oregon, available at $<\mathrm{http}: / / \mathrm{www}$.greenbergresearch.com/index.php?ID=1816>.

214 Id.

215 Id.

216 Memorandum from David Metz, Fairbank, Maslin, Maullin \& Associates, to Opportunity PAC II, Regarding Summary of Key Findings from Oregon Statewide Voter Survey (Mar. 16, 2007), available at http://governor.oregon.gov/Gov/docs/Key

FindingsOregonStatewideVoterSurvey.pdf.

217 Press Release, 1000 Friends of Oregon, Oregonians Change Attitudes on Measure 37 (Feb. 8, 2007), at http:// www.sightline.org/research/sprawl/res_pubs/property-fairness/m37-report-pressrelease.

218 David Steves, Senate Moves Property Rights Measure Forward, REGISTER-GuARD, June 6, 2007. The Governor's efforts were aided by the fact that Democrats took control of both houses of the Oregon legislature in the 2006 election. See Kirk Johnson, The 2006 Elections: The States; In Statehouses, Too, Democrats Post Sizable Gains, N.Y. TIMES, Nov. 9, 2006. 
presented to voters as Measure 49 on November 6, 2007. It passed by a margin of $61 \%$ to 39\%, the same margin by which Measure 37 passed. ${ }^{219}$

By November 2007, Oregonians had turned strongly against Measure 37. One citizen who had previously voted for Measure 37, but changed his mind after his neighbor filed a claim under Measure 37 said: "We didn't get hoodwinked this time. . . We didn't believe all the lies they were trying to spread - and the numbers show it." 220

Unlike Measure 37, which was relatively succinct and straightforward, Measure 49, which was the product of a protracted legislative debate, was a dense 22 pages of complex and confusing language. It is a testament to Oregonians' desire to be rid of Measure 37 that they voted in favor this virtually impenetrable alternative.

Measure 49 essentially rescinded Measure 37's pay-or-waive mandate as to existing laws and regulations and replaced it with a relatively modest, qualified roll back of pre-Measure 37 restrictions on residential development in rural areas for those who previously filed valid Measure 37 claims. As a result, most of the 1970's-era restrictions on development of Oregon's rural lands, especially high-value farm and forest lands, became effective again. As to future regulations, Measure 49 left Measure 37 largely intact, but limited it to restrictions affecting residential development or farm or forest practices, and modified the formula for calculating compensation for regulatory restrictions. The most unpredictable and potentially troublesome aspect of Measure 49 is its application to future laws.

In political terms, Measure 49 represented a compromise designed to satisfy two of the most powerful interest groups in the Measure 37 debate, 1000 Friends of Oregon and the timber industry. The compromise served the interests of 1000 Friends of Oregon by restoring most (but not all) of the restrictions on development of Oregon's agricultural and forest lands. In exchange, the leading financial backers of Measure 37, timber companies, gained significant immunity from future regulation of forestry practices. It was also a compromise uniquely adapted to Oregon, which already had a highly developed land use protection system and where land use advocates were relatively more interested in reestablishing the enforceability of existing regulations than retaining government's long-term flexibility to adopt new regulations.

Measure 49 has several important general provisions, including language prohibiting land owners from seeking compensation or waivers based on regulations restricting industrial or commercial uses (such as billboards, shopping malls, or gravel pits), thereby eliminating one of the

219 Office of the Secretary of State, Elections Division, Official Results for 2007 November Special Election, available at http://www. sos. state. or us/elections/ nov62007/abstract/results. doc

220 Peter Wong, Voters approve modifying land rules; Measure 37 revision wins handily among Mid-Valley voters, STATESMAN JOURnAL, Nov. 7, 2007. 
most controversial features of Measure 37. ${ }^{221}$ In addition, Measure 49 eliminated the prohibition on the transferability of waivers, ${ }^{222}$ established a new formula for determining whether regulations have reduced property values, ${ }^{223}$ and created a cause of action for neighboring land owners adversely affected by Measure 37 decisions. ${ }^{224}$

With respect to land use restrictions in effect prior to January 1, 2007, in lieu of Measure 37's pay or waive mandate, Measure 49 allows owners who previously filed valid claims (or had already been granted waivers) to seek permission to construct either (1) up to three dwelling units on land outside of urban growth boundaries, or (2) up to ten units on (a) land inside urban growth boundaries or (b) land outside urban growth boundaries that is not high-value farmland or highvalue forestland and that is not in a ground water restricted area. ${ }^{225}$ To obtain permission to construct up to three dwellings, the owner is required to show that a current regulation prohibits the construction of units that were otherwise permitted at the time he acquired the property. To take advantage of the second 10-unit option, the claimant also has to demonstrate, using the new formula in Measure 49, that the adoption of the regulation reduced the value of the property. ${ }^{226}$

With respect to future laws and regulations, Measure 49 retains a modified version of Measure 37. The state or local government is required to pay compensation or waive the restriction if a regulation adopted in the future restricts residential development or farm or forest practices and reduces private property values. ${ }^{227}$ In essence, Oregon has adopted a prospective takings measure with respect to residential development and agricultural or forestry practices that is comparable to those adopted in Arizona in 2004 or Florida in 1995.

As discussed, Measure 49 changed the formula for determining whether a regulation reduces property value. In lieu of the traditional with-and-without approach used in constitutional takings cases, Measure 49 defines a reduction in fair market value as being "equal to the decrease, if any, in the fair market value of the property from the date that is one year before the enactment of the land use regulation to the date that is one year after enactment, plus interest." ${ }^{228}$ This methodology applies both to claims based on new regulations and to prior Measure 37 claims where the owner seeks to use the conditional path to obtain permission to develop up to ten

221 H.B. $3540 \S 12$ (limiting compensation to instances where regulation restricts residential uses or farming or forestry practices).

222 H.B. $3540 \S 11$.

223 H.B. $3540 \S \S 4,7(6), 9(6), 12(2), 14,21(b)$.

224 H.B. $3540 \S 16$.

225 H.B. $3540 \$ \S$ 5-10. See also Corey v. Department of Land Conservation and Development, No. SC S054995 (Or. May 8, 2008), available at http://www.publications. ojd.state. or. us/S054995. htm ("An examination of the text and context of Measure 49 conveys a clear intent to extinguish and replace the benefits and procedures that Measure 37 granted to landowners. ").

226 H.B. $3540 \S \S 5-10$.

227 H.B. $3540 \S 12$.

228 H.B. $3540 \S \S 4,7(6), 9(6), 12(2), 14,21(b)$. 
dwellings. The new formula for calculating compensation is more defensible from an economics perspective and is less likely to confer substantial windfalls on land owners than the original Measure 37 formula. However, the new formula is problematic insofar as it assumes that no individual regulation should ever reduce private property values, will likely prove very difficult to apply in practice, and may lend itself to exaggerated claims of financial loss. ${ }^{229}$

\section{What Comes Next?}

Measure 49 decidedly represents a mixed bag. The vote on Measure 49 reflects public rejection of the property rights agenda based on actual experience with the consequences of Measure 37. The experience in Oregon already has and undoubtedly will continue to serve as a cautionary lesson for other states. On the other hand, Measure 49, in its details, is a highly nuanced and complicated political compromise. Measure 49 achieved the primary objective of Oregon land use advocates by reestablishing most of the McCall-era land use protections for Oregon's extensive farm and forest lands. At the same time, as to the future, Measure 49 leaves the core of Measure 37 largely untouched. As one prominent commentator has observed, "Measure 49 retained, at least to a large extent, the promise at the heart of Measure 37-entitling land owners to compensation for loss of value or a regulatory waiver when a government enacts a regulation restricting residential development, agriculture, or forestry practice - thereby curtailing governmental ability to manage future growth." 230

It is difficult to predict how much of a chilling effect Measure 49 will have on future regulatory initiatives and how state and local governments will respond to claims under Measure 49. Oregonians, at least for the time being, have limited their ability to address future land use and environmental challenges. Whether Oregon will learn to live with this uneasy compromise, or eventually reject the property rights agenda not only with respect to pre-existing regulations but also with respect to future law-making, only time will tell.

${ }^{229}$ For a more complete description and analysis of Measure 49, see John D. Echeverria, ANALYSIS OF OREGON HOUSE BILl 3540/MEASURE 49 (GELPI July 17, 2007), available at http://www.law.georgetown.edu/gelpi/current_research/documents/RT_ M49Memo.pdf.

230 Blumm, Enacting Libertarian Property, 85 DENV. U. L. REV. at 365. 


\section{The Lessons Learned}

For several reasons, the experiences in Florida and Oregon with takings legislation were different. The takings measures are (or were) different, the underlying regulatory programs were different, and the historic volumes of growth and development in each state were different. Nonetheless, our review of the experiences in Florida and Oregon (informed as well by the experiences of other states that have adopted similar legislation) suggests five overarching conclusions.

\section{The Takings Agenda Undermines Community Protections}

The takings agenda in Florida and Oregon undermined the public's ability to adopt and/or enforce regulations designed to protect homeowners, the environment, and the community as a whole. What the takings agenda did not foster in either state was a deliberative process allowing officials to modify or repeal regulations that imposed too great a cost relative to their benefits and to retain valuable regulations and arrange payment of compensation to affected land owners. The takings agenda, despite the substantial rhetoric about "compensation," typically did not involve making payments to anyone. Instead, it turned out to be almost exclusively about stopping regulation.

Former Solicitor General Charles Fried famously characterized the property rights agenda: "The grand plan was to make government pay compensation as for a taking of property every time its regulations impinged too severely on a property right-limiting the possible uses for a parcel of land or restricting or tying up a business in regulatory red tape. If the government labored under so severe an obligation, there would be, to say the least, much less regulation." 231

Fried's perceptive description of the ultimate goal of the takings agenda appears to have been borne out by the actual experiences in Florida and Oregon. There is substantial anecdotal evidence from both states that the takings regime had a significant chilling effect on the enactment of new regulations and, in Oregon, resulted in a roll back of existing regulations. The number of times that governments paid compensation to keep regulations in place can be counted on the fingers of one hand.

The uniform deregulatory impact of takings measures does not conform to the expectations of either the proponents or opponents of these measures. As noted, Florida Governor Chiles predicted that the Bert Harris Act would "safeguard[] our environmental and growth-management protections while also offering private property owners a means to seek compensation for devalued

231 Charles Fried, ORdER And LaW, ARguing the REAGAn REvolution-A Firsthand Account 183 (1991). 
land." ${ }^{232}$ The Oregon League of Cities predicted that Measure 37 would produce compensation awards totaling $\$ 3.8$ billion rather than massive deregulation. ${ }^{233}$

Nor does it conform to the predictions of commentators who have argued that the takings agenda should bring more accountability and balance to the regulatory process. For example, E. Donald Elliott wrote that property rights legislation, by "regulating the regulators," creates "incentives for government to design rules more carefully and maximize the environmental benefits of regulatory investments. " 234 In the words of another commentator,

the presence of property rights legislation will require legislators and regulators to balance the costs against the benefits of legislation that would affect private property. If a regulation is determined to be sufficiently important to pay for the impact it will have on land owners - or at least valuable and important enough to run the risk of having to pay for itthen it is more likely to be an effective, worthwhile regulation. If the cost of a regulation is not worth paying for, then perhaps the regulation should not be passed. ${ }^{235}$

A basic assumption underlying this viewpoint has been that a payment requirement would not preclude regulation altogether. Rather, "[a] damages remedy gives the government a choice. It can continue the regulation if it values it above the market price." 236

The reality in Florida and Oregon has been quite different, with state and local regulators waiving, repealing, or simply not adopting all manner of land use and environmental regulations. This effect is partly attributable to the magnitude of the claims, the lack of dedicated funding mechanisms, and the difficulty of determining the appropriate level of compensation. It also may reflect the understandable concern, discussed below, that paying claims might confer windfalls on claimants who have suffered little if any reduction in the value of their properties.

But these on-the-ground results also suggest that the takings agenda is based on a fundamental misconception about the incentives driving official behavior at the state and local levels. As suggested by the statements quoted above, takings advocates generally treat the burdens of compensation awards and the benefits of regulatory programs as commensurate, that is, they assume that paying land owners has the same political significance for state and local decisionmakers as the community-wide benefits of regulation. But, based on the experience in Florida and Oregon, state and local officials are apparently influenced far more by concerns about the impact of compensation awards on their budgets than they are by the effects of widespread waivers on the

232 Roy Hunt, Property Rights and Wrongs: Historic Preservation and Florida's 1995 Private Property Rights Protection Act, 48 FLA. L. REV. 709, 715 (1996).

233 There Goes the Neighborhood, EUGENE WEEKLY, Oct. 7, 2004.

234 Elliott, How Takings Legislation Could Improve, 38 WM. \& MARY L. REV. at 1177.

235 Jeffrey W. Porter, Will Property Rights Legislation Endanger Smart Growth Efforts?, 30 REAL EST. L.J. 275, 301 (2002).

236 William Fischel, REgUlatory TAKINGS: LAW, ECONOMICS, AND POLITICs 364 (Harvard 1995). 
general public welfare. ${ }^{237}$ The political costs of paying expensive compensation claims (and dealing with the resulting budgetary tradeoffs) is apparently far greater than dealing with public complaints about, say, extensive wetlands destruction, or massive traffic congestion, even if these environmental costs are more severe, because these costs tend to be relatively diffuse in space and time. As a result, takings compensation measures do not produce careful calculations of the relative costs and benefits of regulatory programs. Rather, these measures operate through the backdoor to dismantle and prevent regulation altogether.

Special Interests Benefit the Most from the Takings Agenda

While the takings agenda has commonly been portrayed as being for and on behalf of the "little guy," 238 the primary beneficiaries of the takings agenda in Oregon and Florida have been well-heeled special interests.

In Oregon, the timber industry, which provided the most generous financial support to the yes campaign, also filed the largest Measure 37 claims in terms of both acreage and the amount of compensation demanded. Major timber industry contributors to the campaign included Seneca Jones Timber Co. (\$321,000), Dr. Johnson Lumber Company $(\$ 75,000)$, Stimson Lumber Company (\$30,000), Murphy Plywood (\$25,000), Giustina Land \& Timber Co. $(\$ 20,000)$, and SDS Lumber Company $(\$ 7,500) .{ }^{239}$ All told, contributors to the yes campaign filed claims under Measure 37 seeking payments totaling $\$ 600$ million. $^{240}$

While the individual seeking to build a home for himself or his family was the face of the Measure 37 campaign, the majority of applications under Measure 37 to build residences involved multi-unit subdivisions. In terms of acreage, subdivisions with ten or more units represented $70 \%$ of the acreage affected by proposed residential projects.

237 This assessment conforms with thoughtful theoretical analysis of the likely effects of takings compensation regimes on official behavior. Professor Daryl Levinson has explained that there is no "model of government decision making that explains how the social costs and benefits of government activity are systematically translated into private, political costs and benefits for government decision makers, and what role, if any, mandating financial outflows plays in this process." Daryl J. Levinson, Making Government Pay: Markets, Politics, and the Allocation of Constitutional Costs, 67 U. CHI. L. REV. 345, 357 (2000). Absent such a model, he says, "we should have little confidence in any of the conventional assumptions about the deterrent effects of making government pay money" for regulatory impacts on property. Id. at 387.

238 According to one account, the General Counsel of the Florida Farm Bureau commented that property rights advocates had to exploit stories about the "little guy" in order to advance its probusiness agenda. Mary Ellen Klas, Powerful Land Owners Fuel Property Revolt, PALM BEACH PosT, Mar. 11, 1994.

239 Measure 37 Campaign Donors With Measure 37 Claims, at http://www.measure37watch.com/oregon_measure_37/2007/09/measure-37-do-1.html; Measure 37 Campaign Contribution Analysis, at: http://www.democracyreform.org/ ?q=041707release. See also Money in Politics Research Action Project, Donors Who Gave More than Half the Money to the Measure 37 Campaign File Over \$600 million in Claims, Could Earn Windfall on Campaign Investment, Apr. 19, 2007, at http://democracyreform.org/?q=041707release.

240 Id. 
Likewise in Florida, powerful monied interests were behind the push for property rights legislation. U.S. Sugar Corporation, a large Florida agribusiness that owns approximately 190,000 acres in Florida, provided major backing for the constitutional amendment petition that laid the groundwork for eventual adoption of the Bert Harris Act. ${ }^{241}$ Other corporations that owned millions of acres of undeveloped land contributed heavily to the Florida Legal Foundation, the organization that led the drive for property rights legislation, including St. Joe Paper Company, Lykes Brothers, and Collier Enterprises. ${ }^{242}$

Substantial anecdotal evidence, discussed above, demonstrates that large developers have successfully exploited the Bert Harris Act to overcome regulatory obstacles and construct larger and more environmentally intrusive developments than would have been allowed in the absence of the legislation. In general, owners of the largest tracts of undeveloped land have benefited the most.

In both states, the takings agenda has actually undermined the rights and interests of most property owners. Most property owners are homeowners, and they depend on community protections to control activities that could adversely affect the value of their investments.

\section{The Takings Agenda Creates Land Use Conflicts}

Another notable lesson from the Florida and Oregon experiences is that property rights legislation generates controversy and conflict. Measure 37 produced thousands of legal claims and hundreds of lawsuits, and the Florida property rights legislation produced substantial but smaller numbers of claims and lawsuits. All of this legal activity produced neighbor-neighbor conflicts between those seeking to develop their property and those who believed they were protected from harmful development by regulation.

One of the basic purposes of the Oregon land use program is to reduce land use conflicts by separating sometimes inconsistent land uses, such as intensive agricultural and residential uses. Measure 37 fundamentally undermined this policy by authorizing land owners to obtain waivers from the state's comprehensive land use rules. Farmers in areas traditionally devoted exclusively to agriculture found themselves threatened, as a result of Measure 37, with potentially incompatible residential subdivisions next door. The conflicts were exacerbated by the fact that Measure 37 authorized owners to obtain waivers based, not on logical planning principles, but on the happenstance of when they (or an ancestor) acquired the property. As a result, Measure 37 waivers were spread across the landscape in scattershot fashion, maximizing the neighbor-neighbor conflicts.

There are numerous examples of the conflicts generated by Measure 37. Susie Kunzman and other farmers in Clackamas County objected to a neighbor's plan to open a gravel mine by

241 See Lazos Vargas, Florida's Property Rights Act, 23 Fla. ST. U. L. REV. at 329 n. 64. 242 Id. at 329 n. 65. 
invoking Measure 37. ${ }^{243}$ Although County Commissioners were sympathetic to the farmers, they lacked the funds to pay compensation and were forced to waive the regulations. ${ }^{244}$ Marion County Judge Paul Lipscomb, acting as a private citizen, sued the state and his neighbors over his neighbors' plan to subdivide their property, claiming that it would reduce the value of his property. ${ }^{245}$ Farmers Bob and Crystal Vanderzanden filed a lawsuit against the state for approving their neighbor's plan to subdivide a 54-acre property into half-acre lots and build up to 117 homes. ${ }^{246}$ They argued the occupants of these new homes would "complain about the noise, chemical sprays, smells and pollution generated by the agricultural operations, as well as the early hours at which such operations commence, the late hours at which they terminate, and their continuation throughout summer weekends. "247

A report prepared by the Oregon Department of Agriculture mapped the numerous subdivisions that could be developed under Measure 37 in protected farmland, and concluded:

At least 132,346 acres of some of the best farm land in the Willamette Valley could be impacted by development claims made under the Measure 37 property rights initiative. That impact may also cast a shadow on adjacent existing farms by creating compatibility issues between farmers and nearby residents. There may also be impacts on water needed for irrigation. ${ }^{248}$

Based on another estimate, development authorized by Measure 37 could have negatively affected 90\% of the farming operations in Washington County and half of the operations in Hood River County. ${ }^{249}$

Measure 37 also generated conflict by producing "moral hazards," that is, by encouraging property owners, lured by the prospect of a Measure 37 windfall, to advance more intensive development plans then they would have in the absence of the measure. As one commentator put it, Measure 37 "brought out the worst in people." ${ }^{250}$ One striking example is the case of the Palins of Prineville, who, in response to the community's rejection of their application to build a home, formulated a new plan for a more grandiose development on the property. They reasoned that the

243 Sightline Institute, TwO YEARS OF MEASURE 37 at 4-5.

244 Id.

245 Salem judge sues Oregon over Measure 37's effect, CORVALLIS GAZETTE, Nov. 5, 2005; Lauren Oppenheimer, Judge's land-use suit adds ethics to Measure 37 saga, OREGONIAN, Nov. 5, 2005.

${ }_{246}$ Kathleen Gorman, A Measure 37 waiver prompts neighbors to sue, OREGONIAN, July 20, 2006; Sightline Institute, Two YEARS OF MEASURE 37 at 9-10; Second Amended Petition for Review IJ 24, Bob Vanderzanden v. Land Conservation and Development Commission, No. 05C19565 (Or. Cir. Ct.).

247 Id.

248 Oregon Department of Agriculture, Willamette Valley FARMLAND FACES MEASURE37

IMPACT (Feb. 21, 2007), available at http://www.oregon. gov/

ODA/news/070221measure37. shtml.

249 Richmond \& Houchen, MEASURE 37 at 11-13.

250 Randi Bjornstad, Campaign donors file big claims under law, REGISTER-GUARD, Sept. 3, 2006. 
larger their plans, the more money they could get. In another example, a claimant sought payment of \$203 million based on an extravagant proposal to construct "a geothermal power plant an openpit mine containing an estimated 8.5 million cubic yards of high-quality pumice, and a hundred upscale vacation homes equipped with septic tanks and drainfields" on 157 acres alongside a lake in the Newberry National Volcanic Monument. ${ }^{251}$

Similarly, the Florida property rights legislation generated numerous conflicts, ranging from the battle over Stranahan House in downtown Fort Lauderdale to the acrimonious contest over residential development on the outer urbanizing edge of Bartow. More generally, the Florida property rights legislation has fostered a sense of public hopelessness about government's capacity to control the pace and location of development, helping to spawn the Florida Hometown Democracy movement.

Finally, some of the conflict generated by the takings measures is attributable to the legal confusion and uncertainty surrounding the measures. According to some, one purpose of takings measures is to improve on the sometimes confusing and often-maligned constitutional takings doctrine; as stated by one commentator, the Bert Harris Act was intended "to bring clarity to the admittedly muddled body of case law regarding regulatory takings. " ${ }^{252}$ In fact, while constitutional takings doctrine is a matter of continuing debate, the U.S. Supreme Court has succeeded in recent years in bringing relative stability and predictability to this area of law. ${ }^{253}$ Thus, the net effect of the Bert Harris Act has been to generate new questions and uncertainties that will require decades to resolve. As discussed above, the Bert Harris Act, by changing the takings standard, but incorporating familiar terms from constitutional takings doctrine, has created an especially confusing new set of legal rules. Oregon's Measure 37, too, generated many new legal issues, though arguably fewer than the Florida property rights legislation.

The Takings Agenda Confers Special Windfalls on Owners

The popularity of the takings agenda has rested on its appeal to fairness, the idea that the public has a duty to pay compensation (or not enforce a regulation) when a restriction reduces the value of private property. The experience gained from Florida and Oregon reveals the serious flaws in this superficially appealing argument.

First, while certain regulations sometimes burden property owners and reduce property values, comprehensive land use programs, such as those in Oregon and Florida, tend to support and enhance property values. Thus, to the extent the takings agenda assumes that regulatory restrictions generally reduce property values, the entire premise of the takings project is problematic. Second, recognizing that regulations sometimes impose some burden on property owners, paying "just

251 Douglas Larson, Measure 37 puts Newberry Crater at Risk, REGISTER-GUARD, Sept. 11, 2006. 252 See Trevarthen, Advising the Client, 78-AUG. FLA. BAR J. at 63.

253 See Jennifer Bradley, Timothy Dowling, \& Douglas Kendall, Community Rights Counsel, THE Good News About TaKings (American Planning Association 2006). 


\section{Dorothy English}

Ironically, perhaps the most telling illustration of the potentially positive effect of land use regulations, and the potential unfairness of the takings agenda, is provided by the experience of Dorothy English, the most prominent and publicly sympathetic advocate of Measure 37.

The real story about her property, according to news articles and available public records, is that Mr. and Mrs. English bought a 39-acre property in 1953 for \$4,500. ${ }^{\text {a }}$ There were no zoning restrictions on the property at the time of the purchase, and when Multnomah County adopted a zoning ordinance five years later it allowed as many as 42 lots on her property. ${ }^{b}$ The Englishes sold off about 11 acres of the property in 1974 for $\$ 26,400$, and then in 1977 sold off another 9 acres for $\$ 27,000$. In the 1970's, a new 20acre minimum lot size requirement was imposed under the Oregon land use program effectively requiring them to keep the remaining 19 acres intact. ${ }^{\mathrm{c}}$ Land use planners contended that "[s]mall-scale development on land like English's would strain country roads and other services," and that the "property was zoned forestland because its soil is suited to commercial forestry, not suburban construction."d County records indicated that as of 2007, the remaining 19 acres owned by Mrs. English had a market value of $\$ 462,370$, though Mrs. English claimed that they were worth $\$ 600,000{ }^{\text {e }}$ "In investment terms (disregarding the earlier profits from selling off half the property), these figures translate into a rate of return on the original investment of $9.5 \%$ and $10.1 \%$ per year."

In spite of this impressive return on the family's original investment, Mrs. English sought permission to subdivide the remaining property into eight parcels. ${ }^{\mathrm{g}}$ Her Measure 37 claim stated that the property's value would be $\$ 1.75$ million if it could be developed in accordance with this plan. The $\$ 1.75$ million figure represents a rate of return of $12.4 \% .^{\mathrm{h}}$ The County decided to issue a waiver permitting her proposed development to proceed. Nonetheless, claiming that the County was insisting on enforcing certain other restrictions against the property, Mrs. English sued and an Oregon county court awarded Mrs. English $\$ 1.15$ million for the value of her land, plus $\$ 438,000$ in attorney fees. ${ }^{i}$ This litigation has presumably been rendered moot by the enactment of Measure $49 .{ }^{j}$

\footnotetext{
a Georgetown Environmental Law \& Policy Institute, PROPERTY VALUES AND OREGON MEASURE 37; EXPOSING THE FALSE PREMISE OF LAND REGULATION's HARM TO LAND OWNERS 17 (2007).

b Laura Oppenheimer, Breaking Ground Land Owners Who Fought For Measure 37 Ready the First Cases, OREGONIAN, Nov. 22, 2004.

${ }^{\mathrm{c}}$ Id.

d $I d$.

e Georgetown Environmental Law \& Policy Institute, PROPERTY VALUES at 17.

f $I d$.

g $I d$.

${ }^{\mathrm{h}} I d$.

i Still no development on Dorothy English's land, AssOCIATED PRESS, Dec. 25, 2007.

j Id.; Eric Mortenson, Face of Measure 37, Dorothy English, dies, OREGONIAN, Apr. 12, 2008.
} 
compensation" according to the formula in the takings measures effectively grants windfalls that are disproportionate to any injury suffered by the claimants. A compensation award under a takings measure reflects the value of a special exemption from the rules that continue to apply to everybody else, not the amount that would offset any actual regulatory burden suffered by the claimant as a result of the regulation.

The evidence from Oregon demonstrates that the case for Measure 37 was based on wildly inflated estimates of the adverse effect of land use restrictions on private property values. During the debate preceding the 2004 vote on Measure 37, Oregonians in Action asserted that "our planning system lowers the value of private property in Oregon by $\$ 5.4$ billion a year." ${ }^{254}$ But this figure is demonstrably incorrect. Following the adoption of Measure 37, the Georgetown Environmental Law \& Policy Institute, working in collaboration with agricultural economists from Oregon State University and the University of Minnesota, conducted an intensive empirical investigation to determine the actual impact of the Oregon land use program on property values. ${ }^{255}$ This study found no evidence that the Oregon land use program had a systematically adverse effect on private property values. ${ }^{256}$ These findings are consistent with many similar empirical studies conducted elsewhere in the United States documenting that even stringent land use restrictions commonly have little if any adverse effect on private property values. ${ }^{257}$

These empirical findings are consistent with economists' theoretical understandings of how land use regulations ordinarily affect private property values. ${ }^{258}$ On the one hand, land use regulations may have a tendency to reduce property value by restricting permitted land uses and reducing the economic returns available from the land. On the other hand, regulations positively affect property values by protecting amenity values in the community and minimizing conflicts with nearby and adjacent land uses. Regulations also positively affect land values by creating a scarcity of development opportunities, thereby increasing the value of the development opportunities that remain. For example, zoning requirements may reduce the number of buildable lots in the community, but each building lot is likely to be more valuable than it would be in the absence of the program. As a matter of economic theory, it is indeterminate whether the net effect of these

254 David Hunnicutt, Measure 37 Brings Balance to Oregon's Land Use System, LoOKING FORWARD (Oregonians in Action Education Center Sept.-Oct. 2004), available at oia. org/ec. html.

255 Georgetown Environmental Law \& Policy Institute, PROPERTY VALUES AND OREGON MEASURE 37: EXPOSING THE FALSE PREMISE OF REGULATION's HARM TO LAND OWNERS at 1-3, 23-29 (2007).

256 Specifically, a comparison of trends in agricultural land values over time in Oregon and in neighboring states with far fewer development restrictions revealed that Oregon land values increased at about the same rate and sometimes faster than in the other states. Another comparison of trends in land values in Oregon inside and outside urban growth boundaries revealed no systematic reduction in the rate of appreciation of heavily restricted lands outside urban growth boundaries. $I d$.

257 Id.

258 Id. (describing numerous other empirical studies of the effects of land use regulations on private property values). 
different forces will be positive or negative. A recent assessment of the economics of agricultural zoning observed, "Economic theory does not give us a clear answer whether down zoning should decrease or increase property values. " 259

The second major economics problem with the takings agenda is that, even assuming regulations sometimes impose some burden on property owners, the compensation formulas generate monetary awards that amount to unfair windfalls. ${ }^{260}$ The formulas call for a comparison of the market value of an individual parcel subject to the offending regulation with the market value of the property as if the regulation were lifted from that parcel alone. ${ }^{261}$ This with and without approach is inherently problematic because it ignores the fact that the value of the property is influenced not only by the restrictions limiting use of the property but also by application of the same restrictions to neighboring properties. The formula in the takings measures effectively allows a claimant to continue to reap the benefits of regulation of neighboring properties while demanding relief based on the regulatory restrictions that apply to him. This calculation does not capture the amount required to actually compensate an owner for any loss due to regulation, but instead reflects the amount an owner would be paid if he and he alone were entitled to a special exemption from the rules that apply to the rest of the community.

In economic theory, the correct way to measure the effect of a regulation is to ask what the value of the property would be if the regulation had not been adopted and did not apply to anyone in the community. While economists can perform these types of analyses using econometric models, this complex method cannot generally be applied in individual regulatory takings cases and it certainly has never been applied in cases arising under the Bert Harris Act or Measure $37 .{ }^{262}$

Although it is inherently misleading, the with-and-without method is straight-forward and it is the method courts generally use in constitutional takings cases. The important difference in constitutional takings cases is that liability is only triggered if the calculation reveals a very substantial (generally $90 \%$ or more) reduction in property value. This high threshold effectively

259 Jeffrey Michael, et al., DOWNZONING AND RuRAL LAND MARKETs: A REVIEW OF TwO RECENT STUdiES IN MARYLAND AND NEW JERSEY, MCAW Pub. 2006-01 (2006).

260 This issue is discussed in detail in Georgetown Environmental Law \& Policy Institute, PROPERTY VALUES AND OREGON MEASURE 37 at 30-35.

${ }_{261}$ See Opinion, Vanderzanden v. Land Conservation and Development Commission, No. 05C19565 (Or. Cir. Ct. Jan. 8. 2007). An alternative interpretation of Measure 37, advanced by 1000 Friends of Oregon, called for calculating the reduction in property value as of the date of enactment of the measure and then applying an inflation rate to that amount up to the date of the filing of the claim. See Memorandum from Timothy J. Sercombe on the Meaning of "Just Compensation" under ORS 197.352(2) and Modification to Robert E. Stacey. Jr. (June 15, 2006). This approach was difficult to square with the language of the measure, and was apparently adopted by only one jurisdiction. See Oregon State University Study Examines Uneven Approaches To Evaluating Measure 37 Claims, US STATE NEWS, Feb. 8, 2007. This debate was rendered moot by the adoption of Measure 49.

262 See Sullivan, Through a Glass Darkly, 39 URB. LAW. at 576-602. 
incorporates into the analysis the fact that regulations have both positive and negative effects on value. Absent a very severe apparent loss in value using this approach, courts cannot conclude that a claimant has demonstrated any serious economic loss that might justify compensation as a matter of fairness. By contrast, under the takings measures, any adverse impact is sufficient to trigger the need for compensation, yielding routine demands for windfall payments.

Of course, as discussed, under both the Oregon and Florida measures, claims have generally resulted in rollbacks of the challenged regulation rather than payment of compensation. But the economic analysis remains the same. If claimants succeed in using these measures to obtain an exemption from rules that apply to everyone else in the community, and are permitted to develop property in a different and more intensive way than their neighbors, they obtain an economic windfall because the development is more valuable than it would otherwise be. Either way, claimants receive not merely redress for any injuries they may have suffered, but a special boon at public expense.

The Takings Agenda Undermines Local Democracy

The final lesson from Florida and Oregon is that takings measures have undermined opportunities for the public to participate in and influence land use decision making. As discussed, both Oregon's and Florida's land use programs make public participation an integral part of the land use decision making process. The takings measures undermined the public participation goals of both states.

While Measure 37 contained no provision mandating public involvement in the Measure 37 claims process, the measure stated that governments "may adopt or apply procedures for the processing of claims under this act," including procedures related to public involvement. Both the state and many local governments adopted procedures to handle Measure 37 claims. $^{263}$

Notwithstanding this formal opportunity to participate, the public's ability to influence the outcome was limited by a lack of substantive rights in these proceedings. ${ }^{264}$ The negative impact of development on neighbors or the surrounding community was irrelevant under Measure 37, unless the objection could be shoehorned into the measure's relatively narrow exemptions for regulations addressing "public nuisances under common law" (which the measure expressly said "shall be construed narrowly in favor of a finding of compensation under this Act"), or "restricting or prohibiting activities for the protection of public health and safety." Apart from these grounds, the

263 See, e.g., Oregon Land Conservation and Development Department, OR. ADMIN. RULES § 660041 (2007) (establishing procedures for processing Measure 37 claims); Polk County, Measure 37 Processing, available at http://www.co. polk.or.us/M37/

Documents/M37Ordinance.pdf ("Measure 37 does not expressly require public hearings in the course of processing Measure 37 claims. However, decisions of the governing body will be made at the conclusion of a noticed public hearing. . .").

264 By contrast, Measure 49 expressly created a cause of action for neighboring land owners adversely affected by Measure 37 decisions. See H.B. $3540 \S 16$. 
public was left to object about when a regulation was adopted or when the claimant acquired the property or, in a handful cases, whether a restriction on a particular proposed use of property actually reduced the value of the property. ${ }^{265}$

In Florida, the Bert Harris Act's only reference to the public is the provision stating that the government must give written notice of the claim to contiguous owners and to parties to the underlying administrative proceeding. However, the Act grants the public no official standing to participate in settlement discussions under the Act, and the discussions are generally understood to be exempt from Florida's Government in the Sunshine Law. ${ }^{266}$ As a result, settlement discussions under the Bert Harris Act are referred to as "shade meetings." 267 While the government entering into a settlement is supposed to conclude that "the relief granted shall protect the public interest served by the regulation at issue," the public has no formal opportunity to submit comments on whether this standard will be met. Similarly, the Act grants the public no formal opportunity to participate in court proceedings to approve settlements that would contravene a statute.

In any event, in Florida the public has even fewer substantive grounds on which to object than in Oregon. Assuming a claimant can establish a prima facie entitlement to compensation, the public's only significant defense is if the regulatory burdens flow from "governmental abatement, prohibition, prevention, or remediation of a public nuisance at common law or a noxious use of private property." 268 The entire thrust of the settlement process, subject to the general caveat that the "public interest" be served, is to seek some opportunity to ratchet down the regulatory requirements, whether through "[i]ncreases . . in the density. . . [or] intensity" of land uses, "issuance of . . . a variance, special exception, or other extraordinary relief," and so on. ${ }^{269}$

The Dispute Resolution Act provides somewhat greater opportunities for public involvement in that Act's mediation process. But again the entire thrust of the Act is to circumscribe the public's role and limit its ability to raise broader community concerns. The public has no clear entitlement to participate in the mediation process. Even if they are allowed to participate in

265 For example, Ted Warrick, the owner of Wooldridge Creek Winery LLC, successfully challenged the state's grant of a waiver for a gravel mining operation on this basis. See Damian Mann, Wine, and hold the rocks; "Novel" recommendation from land-use agency could crush an Applegate Valley Measure 37 claim, MAIL TRIBUNE, Oct. 11, 2007. Warrick argued that a winery - not a gravel mine - was the highest and best use of the property, and therefore the restrictions did not reduce the property's value. Oregon's Department of Land and Conservation agreed that the best use of the property was as a winery and ultimately withdrew its waiver in October 2007. See Hearings Officer Jackson County, Oregon, Decision and Final Order, In the matter of an Appeal from the Tentative Decision granting approval of a floodplain review on Tax Lot 1101, Township 38 South, Range 4, Case No. ZON2006-02490, Dec. 5, 2007, available at http://www.co.jackson.or.us/files/ZON2006_02490_Krouse_FP_Decn.pdf.

${ }_{266}$ Caren Burmeister, City May Offer Height Cap Claims Settlement, Florida-Times Union, May 21, 2005.

267.

268 FLA. ST. ANN. § 70.001(3)(e).

269 FLA. ST. ANN. § 70.001(4)(c). 
hearings, informal negotiations may occur outside the confines of the formal hearing and the public has no entry point into those discussions. ${ }^{270}$ The Act makes clear that the public has no standing to seek improvements in the underlying regulatory decision that would better protect the public interest. Instead, members of the public can only raise objections to proposed rollbacks of regulatory standards "which may impact their substantial interests." 271 Thus, the entire purpose of the process is to address the concerns of the developer, not to consider the concerns of neighbors or of the community. From a public advocacy perspective, the Dispute Resolution Act is a loser's game, and the only real question is how much the public will lose.

270 Interview with Thomas W. Reese, Attorney, in Tampa, Florida, Feb. 20, 2008.

271 FLA. ST. ANN. $§ 70.51(12)$. 


\section{Georgetown Environmental Law \& Policy Institute Georgetown University Law Center}

The Georgetown Environmental Law \& Policy Institute conducts research and education on legal and policy issues relating to protection of the environment and conservation of natural resources.

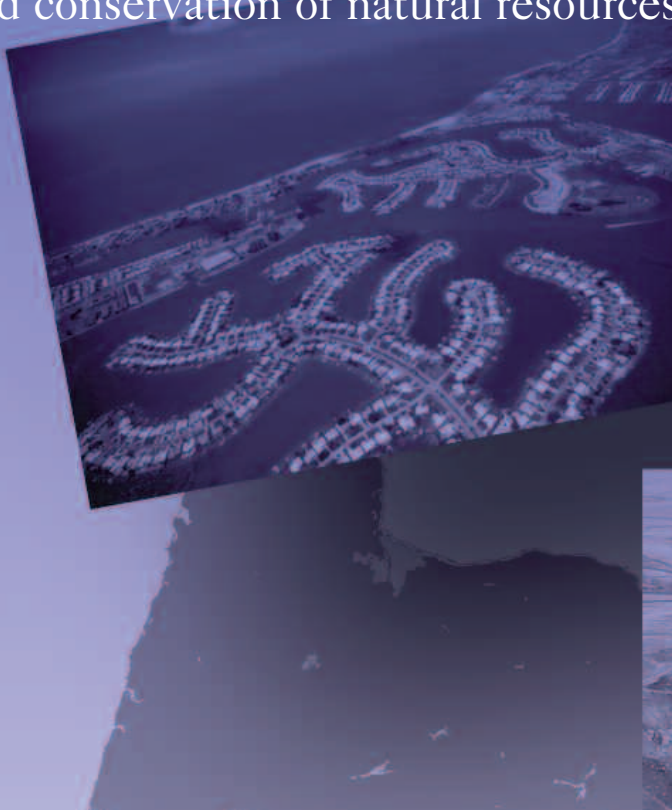
.

For additional copies please contact:

Georgetown Environmental Law \& Policy Institute

Georgetown University Law Center

600 New Jersey Avenue, N.W.

Washington, D.C. 20001

(202) 662-9850
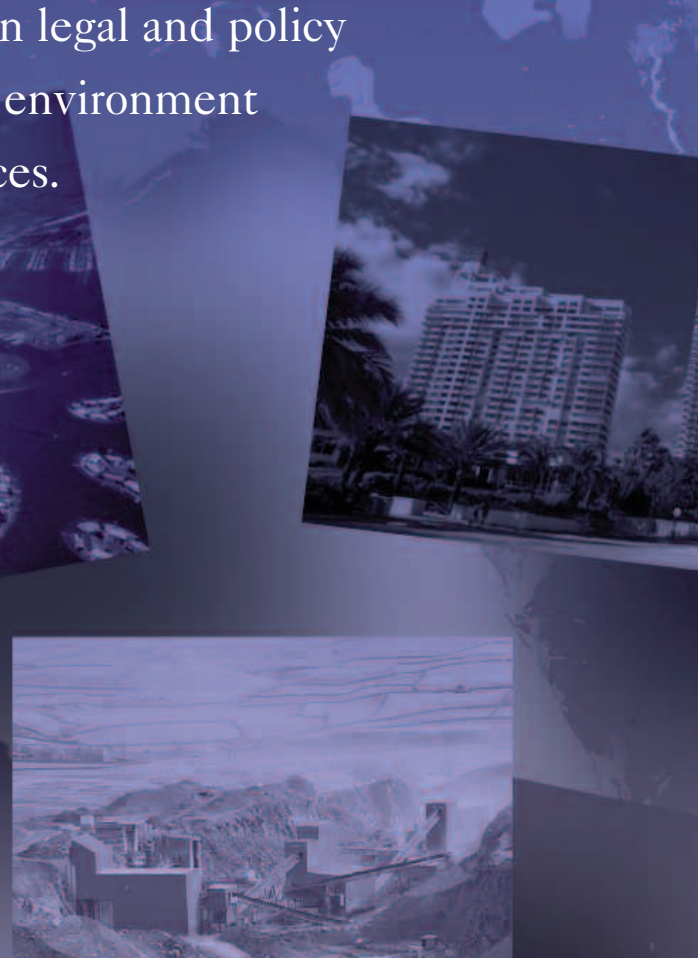

fax (202) 662-9005

gelpi@law.georgetown.edu

PRINTED ON REGYCLED PAPER 